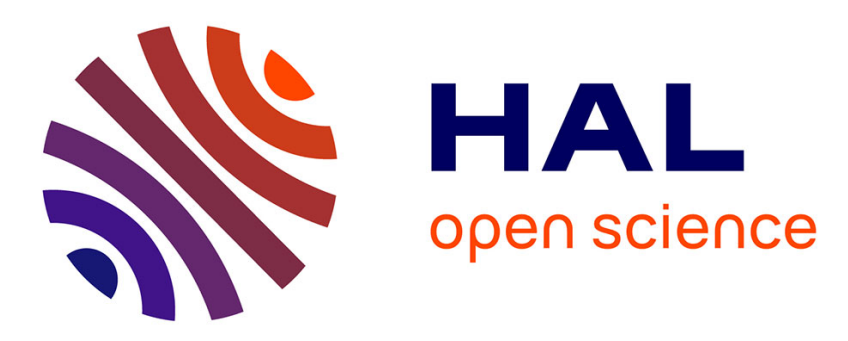

\title{
Submarine groundwater discharge at Forsmark, Gulf of Bothnia, provided by Ra isotopes
}

Lindsay Krall, Giada Trezzi, Jordi Garcia-Orellana, Valenti Rodellas, Carl-Magnus Morth, Per Andersson

\section{- To cite this version:}

Lindsay Krall, Giada Trezzi, Jordi Garcia-Orellana, Valenti Rodellas, Carl-Magnus Morth, et al.. Submarine groundwater discharge at Forsmark, Gulf of Bothnia, provided by Ra isotopes. Marine Chemistry, 2017, 196, pp.162-172. 10.1016/j.marchem.2017.09.003 . hal-01765616

\section{HAL Id: hal-01765616 https://hal.science/hal-01765616}

Submitted on 22 Jun 2018

HAL is a multi-disciplinary open access archive for the deposit and dissemination of scientific research documents, whether they are published or not. The documents may come from teaching and research institutions in France or abroad, or from public or private research centers.
L'archive ouverte pluridisciplinaire HAL, est destinée au dépôt et à la diffusion de documents scientifiques de niveau recherche, publiés ou non, émanant des établissements d'enseignement et de recherche français ou étrangers, des laboratoires publics ou privés. 
3 Submarine groundwater discharge at Forsmark, Gulf of Bothnia,

\section{provided by $R a$ isotopes}

5 Lindsay Krall ${ }^{* 1,2,3}$, Giada Trezzi ${ }^{4}$, Jordi Garcia-Orellana ${ }^{4}$, Valenti Rodella ${ }^{5}$, Carl-Magnus

6 Mörth $^{2}$, Per Andersson ${ }^{3}$

$8 \quad{ }^{1}$ The Swedish Nuclear Fuel and Waste Management Company, Sweden

$9 \quad{ }^{2}$ Department of Geological Science, Stockholm University, Stockholm Sweden

$10 \quad{ }^{3}$ Department of Geosciences, Swedish Museum of Natural History, Stockholm, Sweden

$11{ }^{4}$ Institue de Ciència I tecnologia Ambientals, Universitat Autònoma de Barcelona, Spain

$12{ }^{5}$ CEREGE, Aix-Marseille Université, Aix-en-Provence, France 


\section{Abstract}

Submarine groundwater discharge (SGD) to the Gulf of Bothnia, Baltic Sea, has been believed to be insignificant from hydrological models, yet geochemical investigations of SGD in this basin are limited. In this study, ${ }^{223} \mathrm{Ra},{ }^{224} \mathrm{Ra},{ }^{226} \mathrm{Ra}$, and ${ }^{228} \mathrm{Ra}$ have been complemented by stable $\delta^{18} \mathrm{O}$ and $\delta^{2} \mathrm{H}$ isotopes to characterize and quantify SGD rates from the coast of Forsmark, Sweden to Öregrundsgrepen Strait (Gulf of Bothnia). In shallow bays, SGD has been traced using relations between $\mathrm{Ra}, \delta^{2} \mathrm{H}$ and $\delta^{18} \mathrm{O}$ isotopes and salinity. Zonal SGD from deformation zones, expressed as hydraulically conductive fractures, overlain by the Börstilåsen esker, a strip of conductive gravel sediment, have been traced through offshore ${ }^{224} \mathrm{Ra}_{\mathrm{xs}}$ and ${ }^{226} \mathrm{Ra}$ trends. On the basis of a ${ }^{224} \mathrm{Ra}_{\mathrm{xs}}$ mass balance, the SGD flow rate ranges from $(5.5 \pm 3.0) \cdot 10^{3} \mathrm{~m}^{3} \mathrm{~d}^{-1}$ to $(950 \pm 520) \cdot 10^{3} \mathrm{~m}^{3} \mathrm{~d}^{-1}$. These rates are up to two orders of magnitude higher than those determined from local hydrological models, which consider only the fresh component of SGD. From the divergence between the hydrological and ${ }^{224} \mathrm{Ra}_{\mathrm{xs}}$ models, it is inferred that the site is influenced by a component of recirculated seawater.

\section{Introduction}

Submarine groundwater discharge (SGD) is defined as the flow of water across the sea floor, including the outward flow of fresh meteoric groundwater and the recirculation of seawater through the coastal aquifer (Burnett, 2003; Moore, 2010). In several areas of the world, this process has been recognized as an important pathway for the transport of chemical compounds, including: nutrients (e.g. Rodellas et al., 2015), metals (e.g. Windom et al., 2006; Trezzi et al., 2016), pollutants (e.g. Boehm et al., 2004), and natural radionuclides (e.g. Garcia-Orellana et al., 2013).

The Ra isotope quartet (long-lived ${ }^{226} \mathrm{Ra}$ and ${ }^{228} \mathrm{Ra}$ and short-lived ${ }^{223} \mathrm{Ra}$ and ${ }^{224} \mathrm{Ra} ; \mathrm{t}_{1 / 2} \sim 1600$ $\mathrm{y}, 5.75 \mathrm{y}, 11.4 \mathrm{~d}$, and $3.66 \mathrm{~d}$, respectively) has been used to trace and quantify the flow of 
SGD in several environments, particularly the Pacific, Atlantic, and Mediterranean coasts (Swarzenski et al., 2007; Swarzenski and Izbicki, 2009; Kwon et al., 2014 and references therein). Through application of ${ }^{228} \mathrm{Ra}$, Moore et al. (2008) determined that the rate of SGD to the upper Atlantic Ocean was similar to that freshwater inputs by rivers. Similarly, Kwon et al. (2014) developed a ${ }^{228}$ Ra-based model to estimate the rate of SGD to the Atlantic and Indo-Pacific Oceans and showed that SGD was a major source of nutrients to the oceans. However, a noted source of uncertainty in the model was sparsity of ${ }^{228}$ Ra observations from some areas, for instance the boreal regions, of the global ocean.

From a ${ }^{226}$ Ra model, Destouni et al. (2008) suggested that the discharge of fresh groundwater accounts for $\sim 4 \%$ of the total freshwater inflow to the boreal Baltic Sea. Nevertheless, using natural geochemical tracers off the coast of Poland, Symczycha and Pempkowiak (2016) determined that SGD processes can impact material budgets in the Baltic Sea even alongside low flow rates of fresh SGD. Little is known of SGD-driven material fluxes to the northern and eastern coasts of the Baltic Sea. However, they have been presumed to be less important than to the southern and eastern Baltic coasts (Symczycha and Pempkowiak, 2016).

$\mathrm{Ra}$ isotope methodology is typically applied in saline water due to the potential for $\mathrm{Ra}$ adsorption to particles in low salinity environments (Li and Chan, 1979; Elsinger and Moore, 1980). However, long- and short-lived Ra isotopes may allow various components of SGD to be discriminated, including relative contributions from fresh groundwater and recirculated seawater (e.g. Charette et al., 2008; Rodellas et al., 2017). Therefore, despite the brackish salinity of the Baltic Sea, it is of interest to characterize SGD to the Gulf of Bothnia using Ra isotopes.

Forsmark (Sweden) lies on the southwest coast of the Gulf of Bothnia, the northern-most basin of the Baltic Sea (Figure 1.a). As a current host of a geologic repository for low-level 
radioactive waste and a proposed host of a high-level waste repository, the hydrology and geochemistry around Forsmark have been thoroughly investigated (SKB, 2008). This provides an ideal backdrop to apply Ra isotopes to quantify and characterize SGD in a brackish environment. $\delta^{18} \mathrm{O}, \delta^{2} \mathrm{H}$ and major cation measurements complement the ${ }^{224} \mathrm{Ra}_{\mathrm{xs}}{ }^{-}$ based SGD flow estimates. The purpose of this study is to characterize and quantify SGD from Forsmark to the Gulf of Bothnia through integration of the hydrological knowledge of the site with geochemical and isotopic tracers.

\section{Site background}

Baltic seawater (hereafter "brackish water") is brackish due to mixing between fresh water sourced from the Scandinavian mainland and saline water from the north Atlantic Ocean. The salinity ranges from one in the northern Gulf of Bothnia to nine near the Danish straits. Since seawater exchange through the Danish straits is limited, tidal sea level fluctuations are minor throughout the Baltic Sea (Voipio, 1981). Symczycha and Pempkowiak (2016) have suggested that groundwater discharge to the Baltic Se occurs mainly along the southern and eastern coasts. Through geochemical methods, the rate of fresh SGD to the Bay of Puck, along the Polish coast, was determined to range from $9 \cdot 10^{-4} \mathrm{~m}^{3} \mathrm{~m}^{-2} \mathrm{~d}^{-1}$ to $2.8 \cdot 10^{-2} \mathrm{~m}^{3} \mathrm{~m}^{-2} \mathrm{~d}^{-1}$ and was correlated with monthly precipitation. The recirculated seawater component, with a rate ranging from $4 \cdot 10^{-3}$ to $4 \cdot 10^{-2} \mathrm{~m}^{3} \mathrm{~m}^{-2} \mathrm{~d}^{-1}$ was found to be important (Symczycha and Pempkowiak, 2016).

Forsmark, Sweden lies along the coast of the Öregrundsgrepen strait, within the SubCambrian Peneplain, a widespread, low-relief landscape within Fennoscandia. The $\sim 6 \mathrm{x} 4 \mathrm{~km}^{2}$ area investigated for the repositories reaches a maximum elevation of $\sim 20$ m.a.s.l. Several hydraulically conductive fracture zones intersect the bedrock surface of Öregrundsgrepen, through which the discharge of brackish-to-saline groundwater to the strait is possible 
(Laaksoharju et al., 2008, Figure 1.b. and 1.c). Jarsjö et al. (2008) developed a hydraulic model for the Forsmark site and attributed up to $20 \%$ of the total freshwater input to Öregrundsgrepen $\left(2.4 \cdot 10^{3} \mathrm{~m}^{3} \mathrm{~d}^{-1}\right.$ or $\left.c a .1 .5 \cdot 10^{-4} \mathrm{~m}^{3} \mathrm{~m}^{-2} \mathrm{~d}^{-1}\right)$ to fresh SGD from diffuse sources along the coast.

Deposition of glacial sediments, such as glacial sand and clay, both with low hydraulic conductivities, occurred throughout the Forsmark land and seabed during the Pleistocene glaciations (Hedenström et al., 2008). The Börstilåsen esker, a strip of hydraulically conductive gravel sediments deposited directly over the bedrock surface, extends NW-SE across the land and seabed (Figure 1.a). These deposits are overlain by an Fe,Mn(oxyhydr)oxide-bearing mud (Borgiel, 2004; Voipio, 1981).

Although SGD to the Swedish coast of the Baltic Sea has been presumed low, pockmarks related to permeable layers in glacial clay deposited on the seabed in the Stockholm archipelago, approximately $200 \mathrm{~km}$ from Forsmark, have been observed by Söderberg \& Flodén (1997) and Jakobsson et al. (2016). These formations mark an area of gas (Hovland, 1985) or groundwater escape (Robb 1984) and in this region range from centimeters to tens of meters in size (Söderberg \& Floden, 1997; Jakobsson et al., 2016). Limited geochemical work has been performed alongside the geophysical documentation of pockmarks along the Swedish coast. However, pockmarks on the Baltic coast of Germany were associated with an SGD rate of $9 \cdot 10^{-3} \mathrm{~m}^{3} \mathrm{~m}^{-2} \mathrm{~d}^{-1}$ (Schlüter et al., 2004). Symczycha and Pempkowiak (2016) suggest that discharge to the Baltic coast from glacial sediments has been underestimated. 


\subsection{Field surveys}

116 Three sampling campaigns were performed at Forsmark, in the strait of Öregrundsgrepen, to

117 collect water and sediment samples for Ra and geochemical analysis. In November 2013,

118 three $25 \mathrm{~L}$ samples of seawater were taken directly from the Forsmark shore (S1-S3) and

119 salinities were measured using a YSI-30 probe.

120 A larger campaign in spring 2014 included the collection of water samples from: three five121 station transects (t1-5, t6-10, and t11-15), two stations in the shallow bay Tixelfjärden (TF12), four stations in the larger bay Kallrigafjärden (KF1-4), and five piezometers which represent shallow groundwater (SFM0001, SFM0032, SFM0049, SFM0059, SFM0060; 5 m.b.s.l.). Additionally, deeper groundwater, representative of two of the fracture zones which intersect the bedrock surface of Öregrundsgrepen, was sampled from two boreholes (KFR01, KFR07A; 50 m.b.s.1.) (Figure 1.a, 1.b). At each sea station, $50 \mathrm{~L}$ samples for Ra analysis and $0.5 \mathrm{~L}$ samples for $\delta^{18} \mathrm{O}, \delta^{2} \mathrm{H}$, and major cation analysis, respectively, were filtered through a $0.45 \mu \mathrm{m}$ filter. Salinity profiles were recorded in the field at each station using a YSI-650 probe. Ten-liter groundwater samples were collected for Ra analyses, and $0.5 \mathrm{~L}$ for analyses 130 of $\delta^{18} \mathrm{O}, \delta^{2} \mathrm{H}$, and major cations.

In October 2014, a sediment core was collected from Tixelfjärden bay using a Van Veen grab sampler in order to conduct a Ra diffusion experiment following the methodology used by Rodellas et al. (2012). Fifty liters of seawater overlying the sediment core was also collected

134 for use in the experiment. 

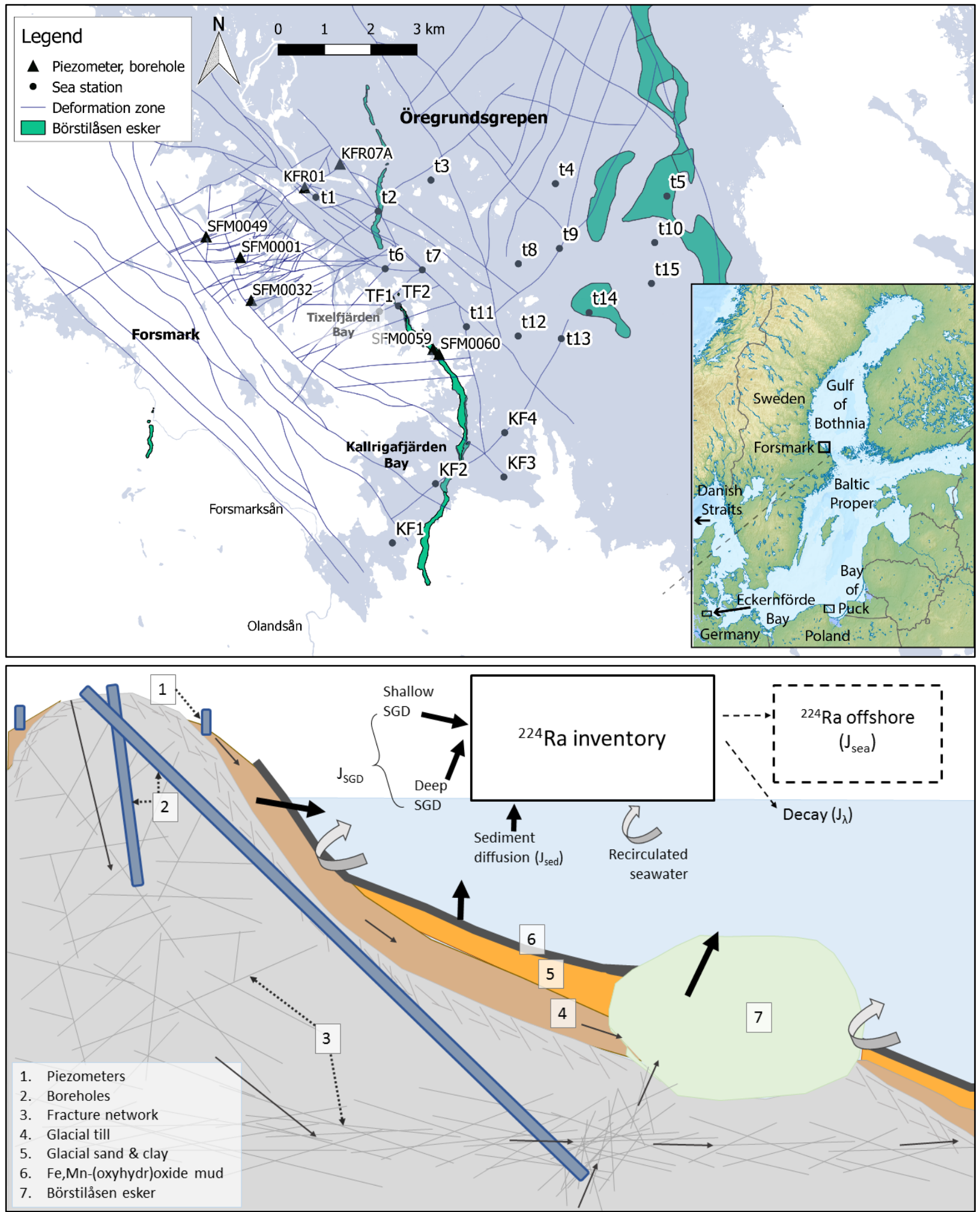

Figure 1: (a) Topographic map of Sweden, including Forsmark and the Gulf of Bothnia in the

Baltic Sea and sampling stations in Forsmark and Öregrundsgrepen, with deformation zones, and Börstilåsen esker. (b) Conceptual illustration of Forsmark fracture network, notable geological formations, groundwater flow (narrow, solid black arrows), and potential $\mathrm{Ra}$ supply and removal processes (box model), modified after Follin et al. (2007). 
$145 \quad 3.2 .1 \quad$ Radium

146 On site, brackish water and groundwater samples were passed through columns loaded with $14725 \mathrm{~g}$ of manganese-impregnated acrylic fiber (hereafter 'Mn-fiber') at a flow rate $<1 \mathrm{~L} \mathrm{~min}^{-1}$ 148 to extract the Ra isotopes (Moore, 1973; Moore et al., 1995). Two water samples were filtered 149 through a series of two columns to check the efficiency of Ra extraction with Mn-fibers. After 150 the Ra extraction, the Mn-fibers were rinsed with Ra-free deionized water and then partially 151 dried (Sun and Torgersen, 1998). The short-lived $\mathrm{Ra}$ isotopes $\left({ }^{223} \mathrm{Ra}\right.$ and $\left.{ }^{224} \mathrm{Ra}\right)$ were 152 measured within seven and three days of collection, respectively, using a Radium Delayed 153 Coincidence Counter (RaDeCC) as described by Moore and Arnold (1996). ${ }^{224}$ Ra activities 154 were corrected for ${ }^{228} \mathrm{Th}$ and uncertainties of ${ }^{223} \mathrm{Ra}$ and ${ }^{224} \mathrm{Ra}_{\mathrm{xs}}$ concentrations were estimated 155 following Garcia-Solsona et al. (2008). Afterwards, the fibers were ashed $\left(820{ }^{\circ} \mathrm{C}, 16 \mathrm{~h}\right)$, 156 ground and transferred to hermetically sealed counting vials to determine long-lived Ra 157 isotopes (Charette et al., 2001). After aging the vials for three weeks to ensure equilibrium 158 between the ${ }^{226} \mathrm{Ra}$ and its daughters, ${ }^{226} \mathrm{Ra}$ and ${ }^{228} \mathrm{Ra}$ were measured using a well-type germanium gamma detector. ${ }^{226} \mathrm{Ra}$ and ${ }^{228} \mathrm{Ra}$ were determined using the ${ }^{214} \mathrm{~Pb}$ and ${ }^{228} \mathrm{Ac}$ photopeaks at 352 and $911 \mathrm{keV}$, respectively. All Ra activities were corrected for radioactive decay since the time of sampling. The relative uncertainties for ${ }^{223} \mathrm{Ra},{ }^{224} \mathrm{Ra} \mathrm{a}_{\mathrm{xs}},{ }^{226} \mathrm{Ra}$, and ${ }^{228} \mathrm{Ra}$ were respectively $13 \%, 14 \%, 7 \%$, and $11 \%$ in the brackish water and $5 \%, 15 \%, 3 \%$, and $3 \%$ in the groundwater.

\subsection{2 $\quad \delta^{18} \mathrm{O}, \delta^{2} \mathrm{H}$}

165 The $\delta^{18} \mathrm{O}$ and $\delta^{2} \mathrm{H}$ values were determined using cavity ring down spectroscopy on a Picaro Isotope Water Analyser, L2140-i, and is expressed vs. Vienna Standard Mean Ocean Water (VSMOW). $\delta^{18} \mathrm{O}$ and $\delta^{2} \mathrm{H}$ values were normalized so that the difference between Standard 
169 for $\delta^{2} \mathrm{H}$. The precision for measurements were $0.1 \%$ for $\delta^{18} \mathrm{O}$ and $0.6 \%$ for $\delta^{2} \mathrm{H}$ based on 170 standards run as samples

$171 \quad 3.2 .3 \quad$ Major cations and trace elements

172 Cations were measured on an ICP-OES using a Thermo ICAP 6500 DUO. Calibrations were 173 made from multi-element standards bought from LGC-PROMOCHEM and calibrations were 174 checked with a certified standard, NIST 1640a. The NIST 1640a were within $\pm 5 \%$ for all 175 elements. Samples were diluted $100 x$ or $10 x$ for major cations and were run undiluted for 176 trace elements. In some cases, an internal standard was used (Y, approx $2 \mathrm{mg} / \mathrm{L}$ ) which was 177 added by having a T-Coupling before the nebulizer (an Ultra Sonic nebulizer, Cetac 178 U5000AT + , were used for trace elements and a VGROOVE nebulizer for major elements). 179 After every 20 samples an internal control were analyzed, which was also used to drift correct 180 data if necessary.

\subsubsection{Diffusive flux experiments}

Quantification of the Ra diffusive flux from the marine sediments was performed in order to check to contribution from of Ra from bottom sediments to the Ra inventory in seawater. The sediment core and $3 \mathrm{~L}$ of the brackish water collected from Tixelfjärden were placed in a plastic container and the sediments were allowed to settle. Brackish water above the core was circulated through a Mn-fiber overnight, to ensure that the water was free of $\mathrm{Ra}$ at the beginning of the experiment. A closed loop system was assembled using a peristaltic pump and plastic tubing, interconnecting the water overlying the core to a column containing Mnfiber. Water continuously circulated through the tubing and the Mn-fiber. Fibers were replaced after progressively longer time periods (12, 24, 48, and 72 hours). Diffusive fluxes for each $\mathrm{Ra}$ isotope were estimated from the slope of the Ra activity versus incubation time regression line, divided by the core surface area plotted against incubation time to obtain fluxes in dpm $\mathrm{m}^{-2} \mathrm{~h}^{-1}$ following the methodology of Rodellas et al. (2012). 
195 The measured salinities, $\mathrm{Ra}$ isotopes activities, $\delta^{2} \mathrm{H}$ and $\delta^{18} \mathrm{O}$ values, $\mathrm{Ba}$ and $\mathrm{Ca}$

196 concentrations and $\mathrm{Ca} / \mathrm{Mg}$ ratios are shown alongside water column depth and distance from

197 shore for each station in Table 1.

198 Table 1: Summary of results for the sampled stations. Depth of water column (DPT), distance

199 from shore (m), and salinity alongside Ra activities in dpm $100 \mathrm{~L}^{-1}, \mathrm{Ba}$ in $\mu \mathrm{g} / \mathrm{L}, \mathrm{Na}$ and $\mathrm{Ca}$ in

$200 \mathrm{mg} / \mathrm{L}$. Uncertainties for $\delta^{2} \mathrm{H}$ and $\delta^{18} \mathrm{O}$ were \pm 0.6 and \pm 0.1 , respectively.

\begin{tabular}{|c|c|c|c|c|c|c|c|c|c|c|c|c|c|c|c|c|c|}
\hline ST & $\begin{array}{l}\text { DPT } \\
\text { (m) }\end{array}$ & Sal & $\begin{array}{l}\text { Dist } \\
\text { (m) }\end{array}$ & ${ }^{223} \mathrm{Ra}$ & $\sigma$ & ${ }^{224} \mathrm{Ra}_{\mathrm{xs}}$ & $\sigma$ & ${ }^{226} \mathrm{Ra}$ & $\sigma$ & ${ }^{228} \mathrm{Ra}$ & $\sigma$ & $\delta^{2} H$ & $\delta^{18} 0$ & $\mathrm{Ba}$ & $\mathrm{Na}$ & $\mathrm{Ca}$ & $\begin{array}{l}\mathrm{Ca} / \\
\mathrm{Mg}\end{array}$ \\
\hline $\mathrm{t} 1 *$ & 6.2 & 4.75 & 220 & 0.67 & 0.10 & 8.1 & 0.9 & 12.8 & 0.6 & 16.1 & 1.1 & -60.1 & -7.9 & 17.0 & 1290 & 59 & 0.37 \\
\hline t2* & 13.4 & 4.71 & 1450 & 0.29 & 0.06 & 2.0 & 0.6 & 12.0 & 0.6 & 15.4 & 0.9 & -60.3 & -8.0 & 16.6 & 1450 & 68 & 0.39 \\
\hline t3* & 6.1 & 4.72 & 2730 & 0.22 & 0.05 & 3.7 & 0.5 & 13.2 & 0.7 & 15.9 & 1.1 & -60.9 & -7.9 & 14.8 & 1490 & 68 & 0.39 \\
\hline $\mathrm{t} 4^{*}$ & 11.8 & 4.63 & 5490 & 0.39 & 0.07 & 3.0 & 0.4 & 15.0 & 0.6 & 15.8 & 0.9 & -60.9 & -8.0 & 15.8 & 1460 & 70 & 0.39 \\
\hline t5 & 33 & 4.64 & 7810 & 0.21 & 0.05 & 1.5 & 0.4 & 14.5 & 0.6 & 15.9 & 1.0 & -60.6 & -8.0 & 15.8 & 1430 & 69 & 0.39 \\
\hline t6* & 10.5 & 4.82 & 310 & 0.30 & 0.07 & 2.3 & 0.7 & 11.6 & 1.0 & 15.8 & 1.0 & -60.5 & -8.0 & 16.9 & 937 & 42 & 0.36 \\
\hline t7* & 10.6 & 4.76 & 1020 & 0.37 & 0.06 & 2.8 & 0.6 & 14.0 & 1.1 & 15.7 & 1.1 & -60.3 & -7.9 & 16.5 & 1405 & 69 & 0.39 \\
\hline t8 & 13.5 & 4.71 & 3100 & 0.38 & 0.06 & 1.7 & 0.5 & 13.3 & 1.6 & 15.2 & 3.4 & -60.4 & -8.0 & 16.1 & 1420 & 70 & 0.39 \\
\hline $10 \mathrm{~m}$ & & 4.79 & & 0.21 & 0.03 & 1.8 & 0.5 & & & & & -60.2 & -7.9 & 16.9 & 1480 & 69 & \\
\hline t9* & 16.3 & 4.70 & 4040 & 0.21 & 0.05 & 2.1 & 0.4 & 15.2 & 0.4 & 16.6 & 2.6 & -60.2 & -7.9 & 16.8 & 1430 & 74 & 0.39 \\
\hline $\mathrm{t} 10$ & 13 & 4.72 & 6130 & 0.24 & 0.06 & 1.4 & 0.4 & 13.5 & 1.2 & 15.7 & 2.2 & -59.9 & -7.7 & 20.3 & & & 0.05 \\
\hline $\mathrm{t} 11^{*}$ & 8.7 & 4.74 & 255 & 0.38 & 0.06 & 2.3 & 0.5 & 13.0 & 1.6 & 16.8 & 3.5 & -60.4 & -8.0 & 16.9 & 1250 & 55 & 0.37 \\
\hline $\mathrm{t} 12^{*}$ & 7.89 & 4.71 & 1280 & 0.20 & 0.05 & 1.8 & 0.4 & 17.6 & 1.1 & 16.1 & 1.0 & -60.0 & -7.9 & 17.0 & 1010 & 45 & 0.36 \\
\hline $\mathrm{t} 13$ & 18.5 & 4.70 & 2170 & 0.28 & 0.06 & 1.3 & 0.4 & 13.8 & 1.1 & 15.4 & 2.4 & -60.9 & -7.9 & 18.6 & 1390 & 65 & 0.39 \\
\hline $10 \mathrm{~m}$ & & 4.72 & & 0.12 & 0.02 & 1.3 & 0.5 & & & & & -60.4 & -7.9 & 16.6 & 1460 & 69 & \\
\hline $\mathrm{t} 14^{*}$ & 21.5 & 4.72 & 2810 & 0.26 & 0.06 & 1.6 & 0.3 & 10.0 & 1.0 & 17.5 & 2.7 & -60.4 & -7.9 & 15.6 & 1450 & 67 & 0.38 \\
\hline $\mathrm{t} 15$ & 20.5 & 4.72 & 4360 & 0.19 & 0.06 & 1.0 & 0.3 & 16.0 & 1.4 & 16.9 & 2.4 & -60.3 & -7.9 & 15.3 & 1440 & 68 & 0.38 \\
\hline KF1 & 4 & 1.71 & 1590 & 1.4 & 0.18 & 13 & 1.2 & 16.4 & 1.3 & 22.9 & 3.6 & -64.8 & -8.6 & 17.9 & 1170 & 68 & 0.47 \\
\hline KF2 & 9.4 & 4.29 & 3250 & 1.2 & 0.15 & 11 & 1.0 & 21.9 & 1.4 & 25.1 & 3.1 & -62.0 & -8.1 & 17.6 & 1340 & 69 & 0.41 \\
\hline KF3 & 7.2 & 4.19 & 4270 & 0.80 & 0.11 & 6.8 & 0.9 & 20.7 & 1.6 & 19.6 & 3.8 & -63.2 & -8.5 & 16.3 & 1110 & 55 & 0.41 \\
\hline KF4 & 8.4 & 4.74 & 4940 & 0.41 & 0.07 & 2.4 & 0.6 & 18.9 & 1.1 & 17.7 & 1.0 & -61.8 & -8.1 & 17.4 & 1390 & 68 & 0.38 \\
\hline TF1 & 3.7 & 4.84 & & 3.7 & 0.31 & 29 & 2.8 & 23.5 & 0.7 & 38.9 & 1.4 & -58.8 & -7.6 & 19.3 & 1450 & 72 & 0.39 \\
\hline TF2 & 1.6 & 4.83 & & 2.8 & 0.18 & 17 & 1.9 & 14.6 & 1.6 & 30.2 & 3.7 & -59.6 & -7.8 & 16.0 & 1470 & 70 & 0.39 \\
\hline S1 & & 4.79 & & & & 16 & 2.5 & 18.1 & 0.7 & 28.4 & 3.8 & & & & & & \\
\hline S2 & & 4.67 & & & & 28 & 3.6 & 32.2 & 2.5 & 48.1 & 3.5 & & & & & & \\
\hline S3 & & 4.81 & & & & 5.0 & 1.4 & 15.6 & 1.6 & 16.2 & 1.1 & & & & & & \\
\hline \multicolumn{18}{|c|}{ Shallow groundwater from piezometer (SFM) } \\
\hline 0001 & & 0.69 & & 8.4 & 1.25 & 220 & 26 & 328 & 26 & 290 & 23.0 & -83.6 & -11.5 & 30.6 & 165 & 83 & 2.8 \\
\hline 0032 & & 0.55 & & 9.2 & 1.12 & 85 & 9 & 203 & 9.0 & 182 & 9.0 & -84.0 & -11.7 & 50.8 & 28 & 135 & 9.9 \\
\hline 0049 & & 0.21 & & 3.9 & 0.55 & 68 & 5 & 50.1 & 2.5 & 95 & 5.0 & -81.7 & -11.1 & 21.4 & 18 & 61 & 8.8 \\
\hline 0059 & & 1.27 & & 5.6 & 0.74 & 270 & 20 & 262 & 12.0 & 287 & 15.0 & -80.5 & -11.2 & 72.5 & 241 & 97 & 3.0 \\
\hline 0060 & & 0.37 & & 4.6 & 0.72 & 73 & 8 & 177 & 9.0 & 143 & 8.0 & -89.8 & -12.6 & 53.9 & 5 & 98 & 12.4 \\
\hline \multicolumn{18}{|c|}{ Deep groundwater (KFR) } \\
\hline 07A & & & & 288 & 11 & 719 & 240 & 1670 & 37 & 2170 & 54.0 & -70.3 & -9.0 & 32.5 & 1530 & 438 & 3.8 \\
\hline 01 & & & & 359 & 19 & 2600 & 290 & 3100 & 70 & 7200 & 197 & -78.7 & -10.3 & 50.6 & 1050 & 620 & 4.8 \\
\hline
\end{tabular}


202 In the transects (stations $t 1-15,1 \mathrm{~m}$ depth) salinity ranged between 4.63 and 4.82 . The salinity 203 in Tixelfjärden bay (TF1-2) was slightly higher than in the offshore transects (4.83-4.84). In 204 Kallrigafjärden bay, the salinity was lower near the streams of Forsmarksån and Olandsån 205 (1.7, KF1) and increased toward the opening of the bay (4.7, KF4).

Salinity variation throughout the water column was within the uncertainty of the measurement $207( \pm 0.1)$, thus stations of $<10 \mathrm{~m}$ depth exhibited no significant change in salinity with depth 208 (Figure 2). Stations with a deeper water column showed a halocline at $\sim 10 \mathrm{~m}$ depth, where 209 salinities decreased from $\sim 4.8$ to $\sim 4.6$ (Figure 2 ).

210 Shallow groundwaters were fresh, with a salinity range 0.4 to 1.3. However, $\mathrm{Cl}^{-}$ 211 concentrations in the deep groundwaters were up to a factor of three greater than brackish 212 Baltic water, thus the deep groundwaters were more saline than the Baltic water.

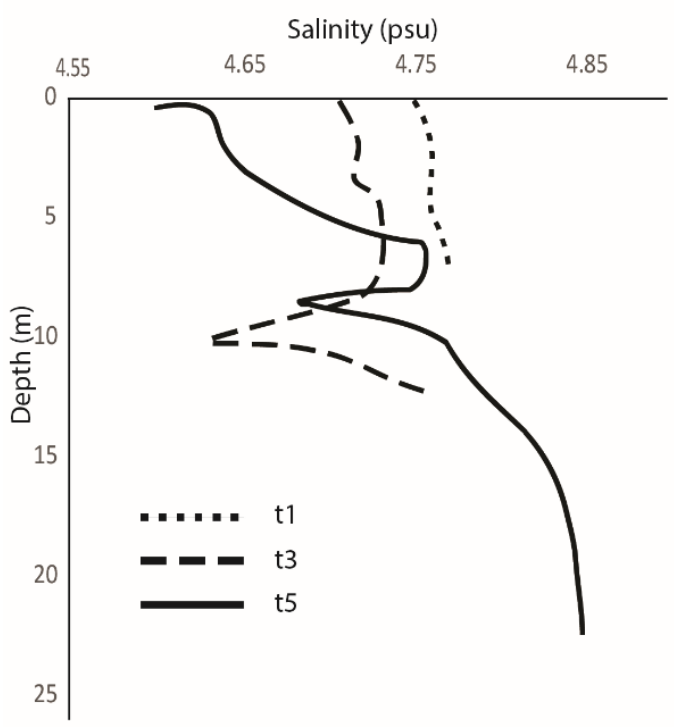

214 Figure 2: Salinity profiles for stations t1 (dashed), t3 (solid), and t5 (dotted). 
216 In the transects, ${ }^{226} \mathrm{Ra}$ and ${ }^{228} \mathrm{Ra}$ activities ranged $10-18$ and $15-18 \mathrm{dpm} 100 \mathrm{~L}^{-1}$,

respectively (Figure 3.a-b). These values are similar to those reported from the central Gulf of

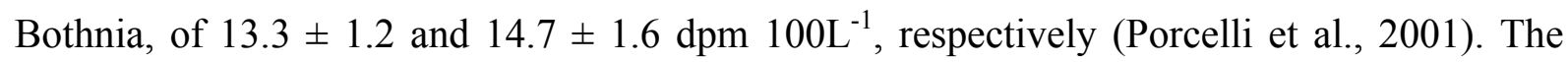
${ }^{223} \mathrm{Ra}$ and ${ }^{224} \mathrm{Ra}_{\mathrm{xs}}$ activities ranged $0.19-0.70$ and $1.0-8.1 \mathrm{dpm} 100 \mathrm{~L}^{-1}$, respectively (Figure 3.c-d). Maximum and minimum activities were found at station $\mathrm{t} 15$ and $\mathrm{t} 1$, respectively. Gradients were observed within the first $2 \mathrm{~km}$ offshore for the short-lived isotopes, particularly ${ }^{224} \mathrm{Ra}_{\mathrm{xs}}$ in transect t1-5 but were not observed for the long-lived isotopes.

In Kallrigafjärden bay, ${ }^{223} \mathrm{Ra},{ }^{224} \mathrm{Ra}_{\mathrm{xs}},{ }^{226} \mathrm{Ra}$, and ${ }^{228} \mathrm{Ra}$ activities ranged $0.4-1.6,2-14,16-$ 19, and $18-23 \mathrm{dpm} 100 \mathrm{~L}^{-1}$, respectively. Activities were higher in Tixelfjärden bay: 2.7 3.7, $17-29,15-24$, and $30-39 \mathrm{dpm} 100 \mathrm{~L}^{-1}$ for ${ }^{223} \mathrm{Ra},{ }^{224} \mathrm{Ra}_{\mathrm{xs}},{ }^{226} \mathrm{Ra}$ and ${ }^{228} \mathrm{Ra}$, respectively. In shallow groundwaters, long-lived Ra activities were $\sim 2$ to 27 -times greater and short-lived Ra activities 0.8 - 270-times greater than the brackish water. ${ }^{223} \mathrm{Ra},{ }^{224} \mathrm{Ra}_{\mathrm{xs}},{ }^{226} \mathrm{Ra}$, and ${ }^{228} \mathrm{Ra}$ ranged $3.3-10,63-290,48-350$, and $90-310 \mathrm{dpm} 100 \mathrm{~L}^{-1}$, respectively, in shallow groundwaters. Deep groundwaters were more enriched, with activities $2-4$ orders of magnitude greater than the brackish water. Deep groundwaters ranged $280-380,470-2900$, $1600-3200$, and $2100-7400 \mathrm{dpm} 100 \mathrm{~L}^{-1}$ for ${ }^{223} \mathrm{Ra},{ }^{224} \mathrm{Ra}_{\mathrm{xs}},{ }^{226} \mathrm{Ra}$, and ${ }^{228} \mathrm{Ra}$, respectively. Minimum activities for the four Ra isotopes were found in SFM0049, while maximum activities in SFM0032 $\left({ }^{223} \mathrm{Ra}\right)$, SFM0059 $\left({ }^{224} \mathrm{Ra}_{\mathrm{xs}}\right)$, and SFM0001 $\left({ }^{226} \mathrm{Ra}\right.$ and $\left.{ }^{228} \mathrm{Ra}\right)$.

\section{$4.3 \delta^{2} H$ and $\delta^{18} O$ values}

Shallow groundwaters were distinct from, while deep groundwaters were similar to, the brackish water with respect to $\delta^{2} \mathrm{H}$ and $\delta^{18} \mathrm{O}$ values (Table 1). This is because the $\delta^{2} \mathrm{H}$ and $\delta^{18} \mathrm{O}$ signature of the deep Forsmark groundwaters was imparted by a component of Littorina Sea $(7000$ - 9000 BP predecessor to the Baltic Sea), whereas the shallow groundwater 
239 signature was imparted by current meteoric waters $\left(-89.8\right.$ to $-80.5 \% \delta^{2} \mathrm{H}$ and -12.6 to -

$24011.1 \%$ o $\left.\delta^{18} \mathrm{O}\right) . \delta^{2} \mathrm{H}$ and $\delta^{18} \mathrm{O}$ in the transects ranged -60.9 to $-59.9 \%$ o $\delta^{2} \mathrm{H}$ and -8.0 to $-7.7 \%$

$241 \delta^{18} \mathrm{O}$, respectively. A mixing line between the Forsmark data and results from the central

242 Baltic Sea (Fröhlich et al. 1988) as an offshore end-member, deviate from the local meteoric

243 water line due to the increased influence of evaporation in the open Baltic (Figure 4).

244 Brackish water in Tixelfjärden bay was enriched in heavy isotopes (maximum $-58.8 \%$ o $\delta^{2} \mathrm{H}$ 245 and $-7.59 \% \delta^{18} \mathrm{O}$ ) relative to the transects, suggesting a local influence of evaporation, which 246 can produce this heavy signature. Application of the model by Frölich et al. (1988) to the 247 Forsmark coast indicates that the rate of evaporation from Tixelfjärden bay is $15 \%$ of the rate 248 of water inflow from Öregrundsgrepen to Tixelfjärden bay. This is corroborated by Engqvist 249 et al. (2006), who demonstrated a faster rejuvenation of water towards the center of the strait. 250 The lighter signature (lower isotope values) in Kallrigafjärden bay is reminiscent of influence 251 by current meteoric water. 

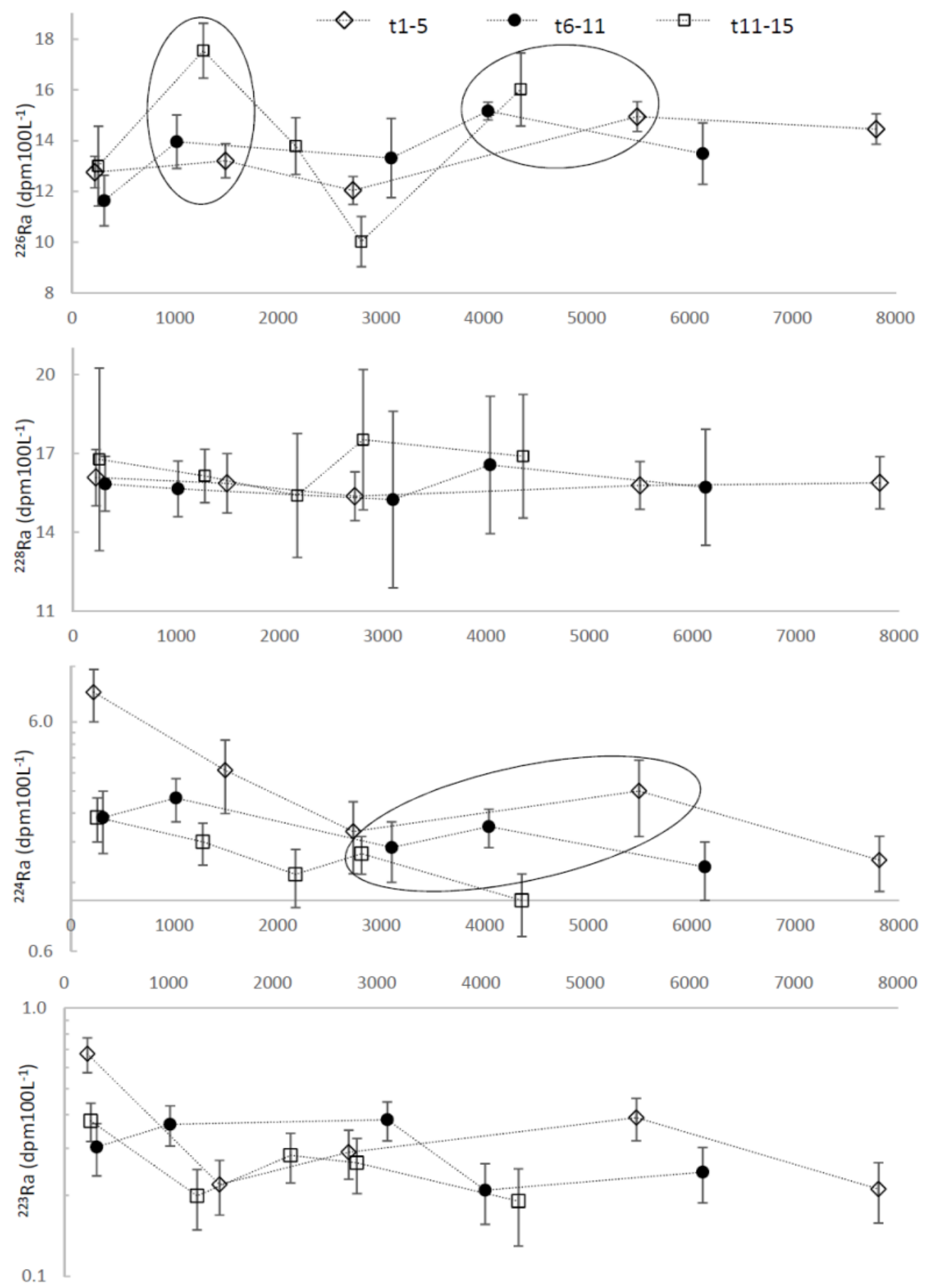

254 Figure 3.a-.d: ${ }^{226} \mathrm{Ra}$ and ${ }^{228} \mathrm{Ra}(\mathrm{a}-\mathrm{b})$ and ${ }^{224} \mathrm{Ra}_{\mathrm{xs}}$ and ${ }^{223} \mathrm{Ra}(\mathrm{c}-\mathrm{d})$ activities as a function of 255 distance offshore (m). Circle to indicate systematic increases in ${ }^{224} \mathrm{Ra}_{\mathrm{xs}}$ and ${ }^{226} \mathrm{Ra}$ activity. 
258 Geochemical results $(\mathrm{Na}, \mathrm{Ca}, \mathrm{Ca} / \mathrm{Mg}$, and $\mathrm{Ba})$ are presented in Table 1. Ba exhibits chemical

259 behavior similar to $\mathrm{Ra}$ due to size and ionic radius. $\mathrm{Ca} / \mathrm{Mg}$ ratios can be used to trace mixing 260 between groundwaters and brackish water, as $\mathrm{Ca}$ in groundwater is predominantly sourced by 261 aquifer solids whereas $\mathrm{Mg}$ by the brackish water (Smellie et al. 2008). Therefore, 262 geochemistry may be used to investigate Ra geochemistry and mixing between ground- and 263 brackish Baltic water. Ba concentrations ranged $15-20 \mu \mathrm{g} \mathrm{L}^{-1}$ in the brackish water, $21-73$ $264 \mu \mathrm{g} \mathrm{L}^{-1}$ in the shallow groundwater, and $33-51 \mu \mathrm{g} \mathrm{L}^{-1}$ in the deep groundwater. However, Ca 265 is more enriched than $\mathrm{Ba}$ in groundwater relative to seawater. Deep groundwater

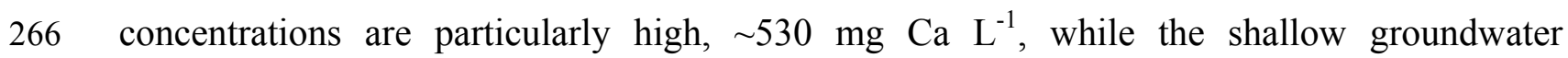

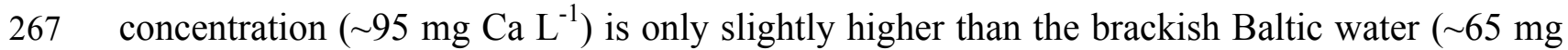

$268 \mathrm{Ca} \mathrm{L}^{-1}$ ). Groundwater $\mathrm{Ca} / \mathrm{Mg}$ ratios are over an order of magnitude higher than brackish water 269 ratios. 


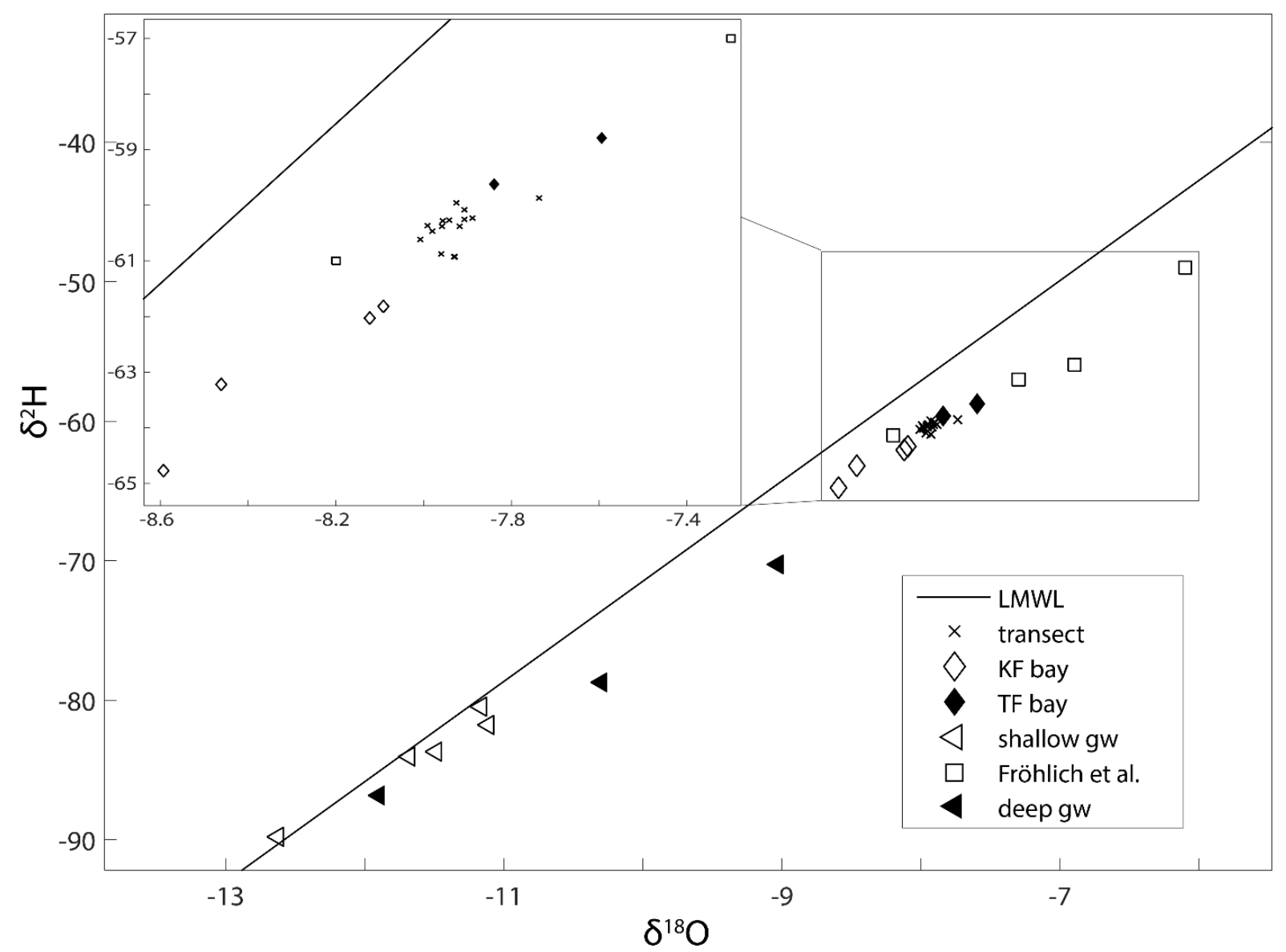

Figure 4: $\delta^{2} \mathrm{H}$ and $\delta^{18} \mathrm{O}$ of groundwater and seawater samples, samples of Fröhlich (1988), and the 272 local meteoric water line (LMWL; Tröjbom et al., 2007).

\subsection{Ra diffusion from sediments}

275 Sediment diffusion experiment results were used to derive the flux of Ra diffusion from the fine-grained, Fe,Mn (oxyhydr)oxide-bearing sediments deposited over the Öregrundsgrepen seabed. Calculated ${ }^{223} \mathrm{Ra}$ and ${ }^{224} \mathrm{Ra}_{\mathrm{xs}}$ diffusion rates amount to (2.2 \pm 0.02$)$ and $(32 \pm 2) \mathrm{dpm}$

$278 \mathrm{~m}^{-2} \mathrm{~d}^{-1}$, respectively (Figure 5). These represent upper limits because during the experiment 279 Ra was continuously removed from the water overlying the sediment core, thereby forcing diffusion by maximizing the gradient between the porewater and the overlying water.

281 Diffusion-sourced ${ }^{226} \mathrm{Ra}$ and ${ }^{228} \mathrm{Ra}$ fluxes are locally insignificant because the rate of their 282 production by Th parents is slow (Rodellas et al., 2015) relative to the residence time within 283 Öregrundsgrepen. The ${ }^{224} \mathrm{Ra}_{\mathrm{xs}}$ diffusion rate is similar to that reported from the Venice 
Lagoon (32 dpm d ${ }^{-1} \mathrm{~m}^{-2}$; Garcia-Solsona et al., 2008) and Jamaica Bay (28 dpm d $\mathrm{d}^{-1}$; Beck et al., 2007) but lower than that reported from Long Island Sound ( $>127 \mathrm{dpm} \mathrm{m}^{-2} \mathrm{~d}^{-1}$; Garcia Orellana et al., 2014) and the Port of Maó (110 dpm m $\mathrm{d}^{-1}$; Rodellas et al., 2015).

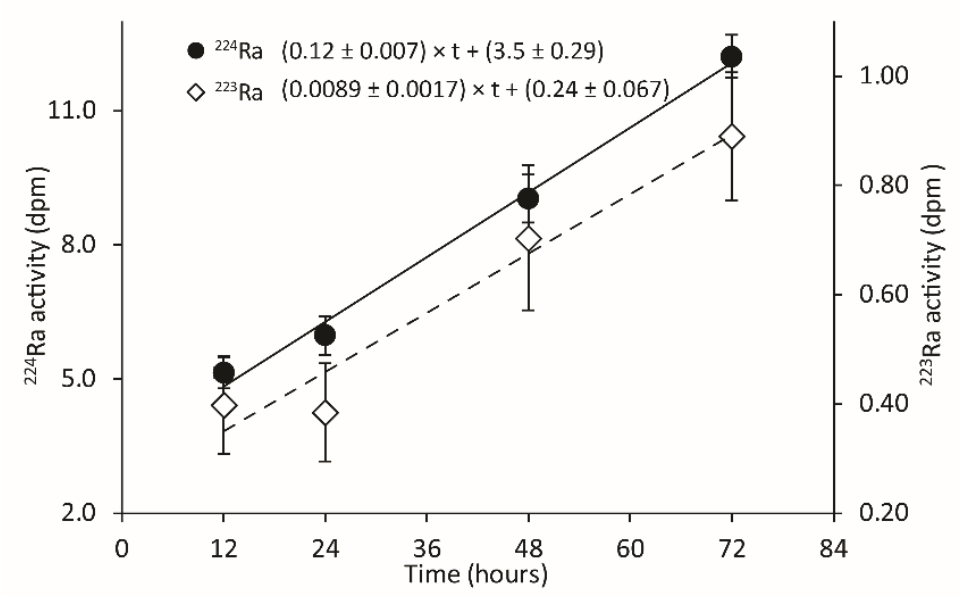

Figure 5: Diffusive ${ }^{223} \mathrm{Ra}$ and ${ }^{224} \mathrm{Ra}$ activities as a function of time (not corrected for surface area of core, $0.091 \mathrm{~m}^{2}$ ).

\section{Discussion}

\subsection{Geochemical behavior of Ra}

Ra exhibits expected salinity-dependent ion exchange behavior, where $\mathrm{Ra}$ in fresh water is predominantly adsorbed to particles. When these particles are transported to saline water, the Ra adsorbed to the particles desorbs after exchange for cations that are enriched in seawater relative to fresh water, particularly $\mathrm{Na}$. Thus, $\mathrm{Ra}$ isotopes may lead to an underestimation of SGD if utilized in fresh waters, in which Ra is likely by adsorption attached to particles.

The salinity after which Ra behaves conservatively is unclear. Gonneea et al. (2008) and Gu et al. (2012) stated that complete Ra desorption is produced above salinities of $10-15$, whereas Krest et al. (1999) and Su et al. (2015) suggest a salinity of approximately five. The former authors attributed the variation in Ra adsorption to differences in particle chemistry and size. Experiments in sandy terrains showed that adsorption of Ra to particles is negligible 
below $\sim 1.8$ (Raanan Kiperwas, 2011). In Öregrundsgrepen, the salinity does not exceed five. Since only the study by Raanan Kiperwas (2011) supports conservative behavior of Ra at salinities less than five, it should be examined whether Ra is an appropriate tracer to apply in the brackish Öregrundsgrepen water.

In seawater, $\mathrm{Ra}$ desorption is promoted because it is outcompeted by $\mathrm{Na}$ for exchange sites, the latter of which is several orders of magnitude more enriched in seawater than in freshwater. Since exchange of $\mathrm{Ra}$ for $\mathrm{Na}$ is a heterovalent cation exchange process, the

309 reaction involves exponential terms and is influenced by total ionic strength of the solution.

310 Nevertheless, an ion exchange model can be used to understand competition between 311 monovalent and divalent cations for adsorption sites at a range of salinities, assuming that $\mathrm{Ra}$ 312 sorption is controlled by an ion exchange rather than a surface complexation mechanism. 313 Equilibrium between a monovalent and divalent cation is expressed by the mass action 314 equation (1):

$$
\frac{X_{C a-c l a y}}{X_{N a-c l a y}^{2}}=K \frac{m_{C a^{2+}}}{m_{N a^{+}}^{2}}
$$

where $X$ represents the fractional equivalents of the mono- or divalent cation in the solid phase, $m$ the dissolved molar concentrations, and $K$ the composition-dependent selectivity coefficient of the particle. Here, the monovalent cations are represented by $\mathrm{Na}$ concentrations in freshwater, brackish Baltic water, and seawater because $\mathrm{Na}$ is the most abundant cation in

320 brackish and seawater. Divalent cations are represented by concentrations of $\mathrm{Ca}$, which is 321 more similar to $\mathrm{Ra}$ than $\mathrm{Mg}$ in size and therefore exhibits more comparable ion exchange behavior.

323 Ca should not exceed $10 \%$ of the total $\mathrm{Na}$ and $\mathrm{Ca}$ adsorbed in brackish water unless $\mathrm{K}(\mathrm{Na} / \mathrm{Ca})$ exceeds 200 (Figure 6). For reference, $\mathrm{K}(\mathrm{Na} / \mathrm{Ca}$ ) values for montmorillonite, a clay with 
strong adsorptive properties, range from 2.5 to 6 depending on the ratio of solid to water $(25 \mathrm{~g}$ $\mathrm{L}^{-1}$ and $2.5 \mathrm{~g} \mathrm{~L}^{-1}$, respectively; Tertre et al., 2011). Through comparison between these selectivity coefficients, it is inferred that brackish water is more similar to seawater than to fresh water with respect to competition between monovalent and divalent cations. Since adsorption of $\mathrm{Ca}$ to particles is not significant in brackish water and the ion exchange

330 behavior of $\mathrm{Ra}$ is comparable to that of $\mathrm{Ca}$ due to size and ionic radius, adsorption of the $\mathrm{Ra}$

331 to particles should not hinder its application in these brackish waters.

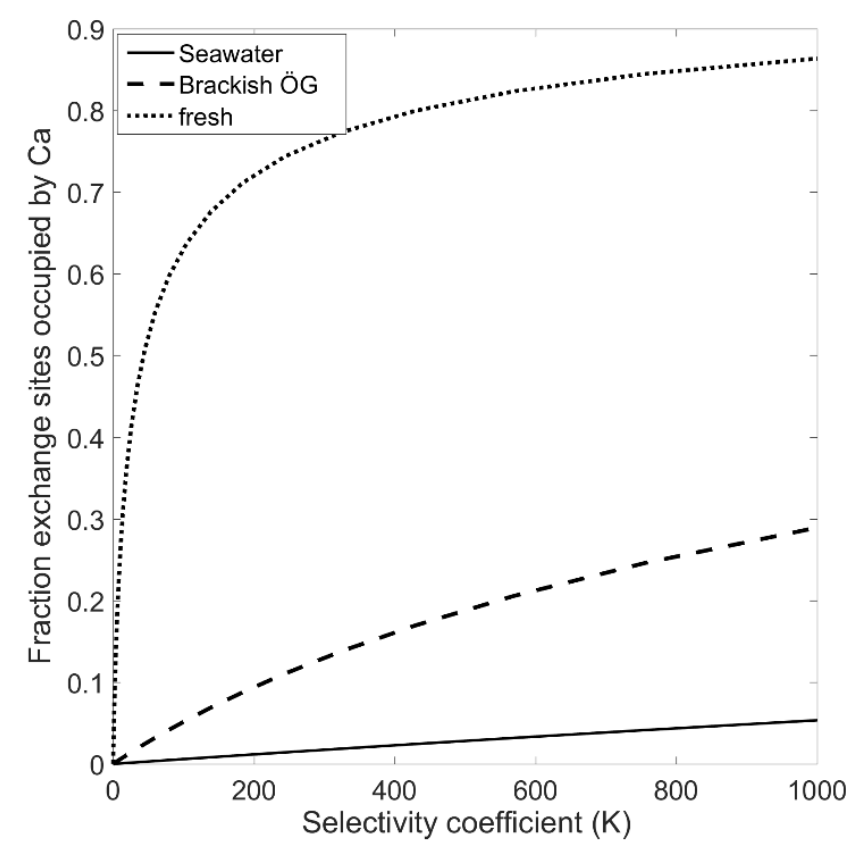

333 Figure 6: Fractional occupancy of $\mathrm{Ca}$ on solid phase for seawater, brackish water, and fresh water as a function of selectivity coefficient $(\mathrm{K})$.

\subsection{End-member mixing}

To determine an accurate SGD flow rate, an appropriate endmember groundwater Ra activity 338 should be selected. It would be particularly valuable to distinguish between the discharge of 339 deep and shallow groundwater, because the former were found to contain Ra in activities up 340 to two orders of magnitude higher than the latter. Salinity, stable $\delta^{2} \mathrm{H}$ and $\delta^{18} \mathrm{O}$ values, and $341{ }^{228} \mathrm{Ra} /{ }^{226} \mathrm{Ra}$ activity ratios (ARs) have been used to define endmember groundwater components during SGD investigations in the Mediterranean (Povinec et al. 2006; Garcia- 
343 Solsona et al. 2010; Rodellas et al., 2014), while $\mathrm{Ca} / \mathrm{Mg}$ ratios are potentially useful at 344 Forsmark (Section 4.4).

${ }^{228} \mathrm{Ra} /{ }^{226} \mathrm{Ra}$ ARs in the Forsmark groundwaters $(0.75-2.40)$ do not differ substantially from 346 those in the coastal and offshore brackish Baltic water $(0.84-2.07$; Figure 7.a). ARs in 347 Tixelfjärden are slightly higher than in the transects, but whether this is due to the discharge 348 of deep or shallow groundwater cannot be distinguished from these data (Figure 7.a). Overall, $349{ }^{228} \mathrm{Ra} /{ }^{226} \mathrm{Ra}$ ARs are inadequate to define the source of groundwater discharge. Salinity, $\delta^{2} \mathrm{H}$, 350 and $\mathrm{Ca} / \mathrm{Mg}$ variations between groundwater and brackish water (Figure 7.b-d) are more 351 significant than ${ }^{228} \mathrm{Ra} /{ }^{226} \mathrm{Ra}$ ARs. No clear mixing relation between groundwater and brackish

352 Baltic water for $\delta^{2} \mathrm{H}$ and ${ }^{226} \mathrm{Ra}$ is observed. However, the $\mathrm{Ca} / \mathrm{Mg}$ ratios and salinity versus 353 ${ }^{226} \mathrm{Ra}$ may indicate mixing between groundwater and brackish Baltic water. Provided the elevated $\mathrm{Ca} / \mathrm{Mg}$ ratio and salinity in Tixelfjärden bay, local discharge of deep groundwater is 355 viable.

\subsection{Zonal SGD}

\subsubsection{Offshore transects}

Fractures intersecting the bedrock surface of the Öregrundsgrepen seabed and the Börstilåsen esker described as potential discharge zones (Section 2) are prevalent through the shallow bays Tixelfjärden and Kalligafjärden and up to $6000 \mathrm{~m}$ off the Forsmark coast (Figure 1.a). Higher average ${ }^{223} \mathrm{Ra}$ and ${ }^{224} \mathrm{Ra}_{\mathrm{xs}}$ activities were observed around the northern-most transect

$362(\mathrm{t} 1-5)$, where the frequency of fractures intersecting the seabed is greatest. Although strong 363 gradients in ${ }^{226} \mathrm{Ra}$ were not observed here, slight increases in offshore ${ }^{224} \mathrm{Ra}_{\mathrm{xs}}$ and ${ }^{226} \mathrm{Ra}$ activities are associated with the occurrence of these fractures $\sim 1000-1500$ and $4000-5000 \mathrm{~m}$ offshore (3.a, 3.c). Systematic increases in Ra are associated with the fracture zones in each offshore transect, and thus may reflect Ra inputs from these zones. 
5.3.2 Tixelfjärden bay

368 Maximum brackish water Ra activities were observed in Tixelfjärden bay. Though the

369 influence of ${ }^{223} \mathrm{Ra}$ and ${ }^{224} \mathrm{Ra}$ diffusion from sediments is more conspicuous in shallow bays

370 due the larger sediment surface area to water volume ratio, ${ }^{226} \mathrm{Ra}$ and ${ }^{228} \mathrm{Ra}$ activities, which

371 are not supplied through sediment diffusion, were elevated in this bay by a factor of two

372 relative to the offshore transects. Given high fracture frequency within the bay and the

373 proximity of the Börstilåsen esker alongside the $\mathrm{Ca} / \mathrm{Mg}$ ratio (Section 5.3.1), $\mathrm{SGD}$ is a

374 plausible local source of Ra enrichment. The rate of evaporation in this bay is $\sim 15 \%$ the rate

375 of water inflow from the strait (Section 4.3) and cannot explain the Ra enrichment. 

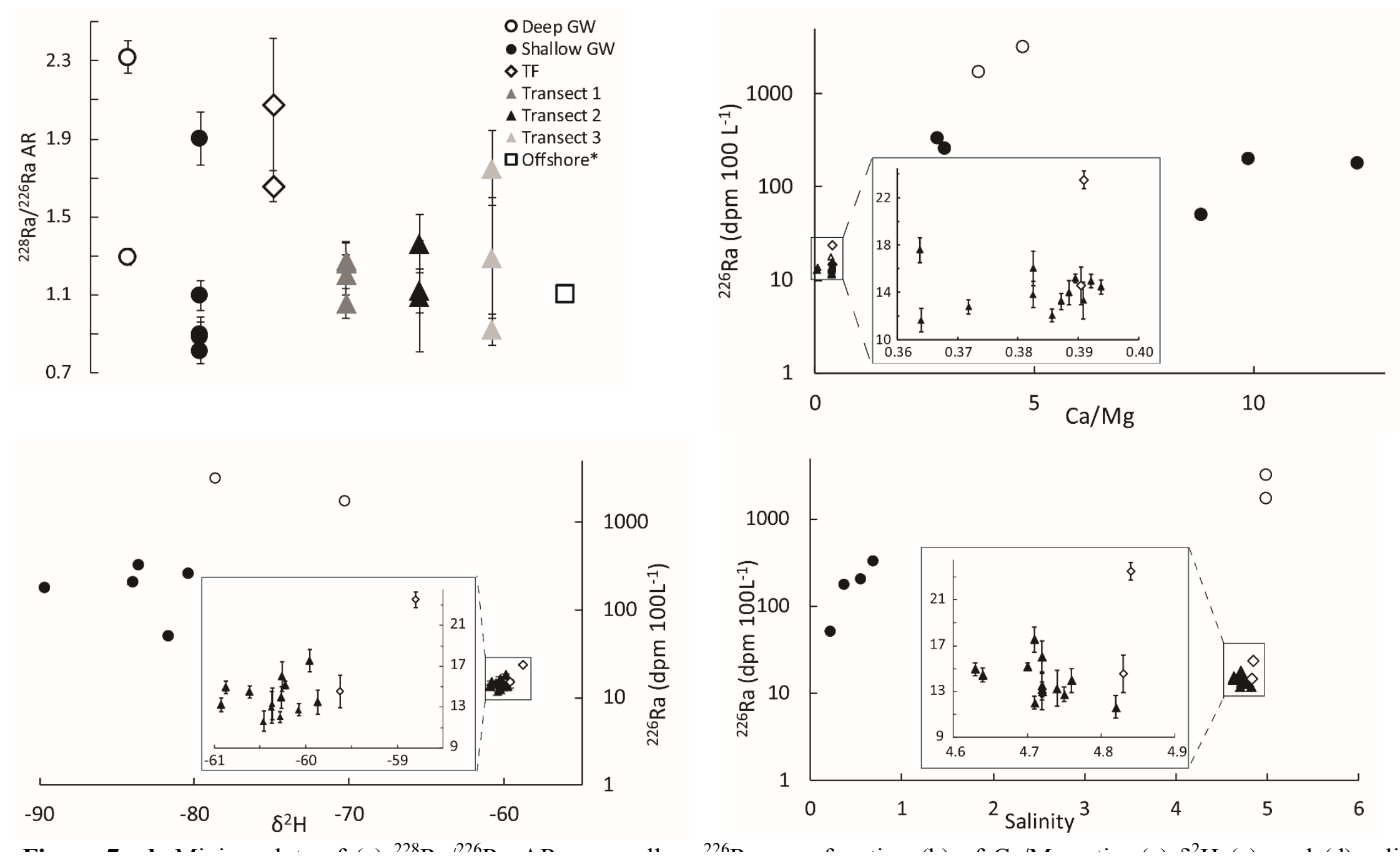


\subsubsection{Kallrigafjärden bay}

Geochemical relationships in Kallrigafjärden bay are influenced by the streams Forsmarksån and Olandsån, which discharge into the western-most regions of the bay, in addition to possible SGD from local deformation zones and the Börstilåsen esker. Mixing between fresh stream water and brackish seawater is indicated by the relation between salinity and $\delta^{2} \mathrm{H}$ (Figure 8.a; Fröhlich et al., 1988).

Streams can transport Ra, which is enriched by as great as a factor of six at the outlets as compared to the mouth of Kallrigafjärden bay. Although short-lived ${ }^{223} \mathrm{Ra}$ and ${ }^{224} \mathrm{Ra}_{\mathrm{xs}}$, like $\delta^{2} \mathrm{H}$, are inversely related to salinity (Figure 8.b), significant Ra input from the streams is not necessarily indicated. A shallow water column is prevalent near the stream outlets, thus ${ }^{223} \mathrm{Ra}$ and ${ }^{224} \mathrm{Ra}$ may be sourced predominantly by sediment diffusion to the shallow water column near the stream outlets. ${ }^{226} \mathrm{Ra}$ and ${ }^{228} \mathrm{Ra}$, which are not significantly supplied by seabed sediments, are highest toward the center the bay.

Relations between salinity and ${ }^{223} \mathrm{Ra},{ }^{224} \mathrm{Ra}_{\mathrm{xs}}, \delta^{2} \mathrm{H}$, and $\delta^{18} \mathrm{O}$ values in Kallrigafjärden deviate from a linearity (Figure 8.a-b), which implies an additional source of Ra and $\delta^{2} \mathrm{H}$. The deviation is apparent around the central stations proximal to the Börstilåsen esker (KF2 and KF3). Likewise, elevated ${ }^{226} \mathrm{Ra}$ and ${ }^{228} \mathrm{Ra}$ activities are found at these stations (Figure 8.c). Despite a salinity increase to $>4$ as compared to 1.7 near the outlet of the streams (KF1), Ra desorption from suspended riverine particles would not explain the deviation in $\delta^{2} \mathrm{H}$ and $\delta^{18} \mathrm{O}$. Therefore, as in Tixelfjärden bay, SGD to Kallrigafjärden bay is a plausible source of Ra. 

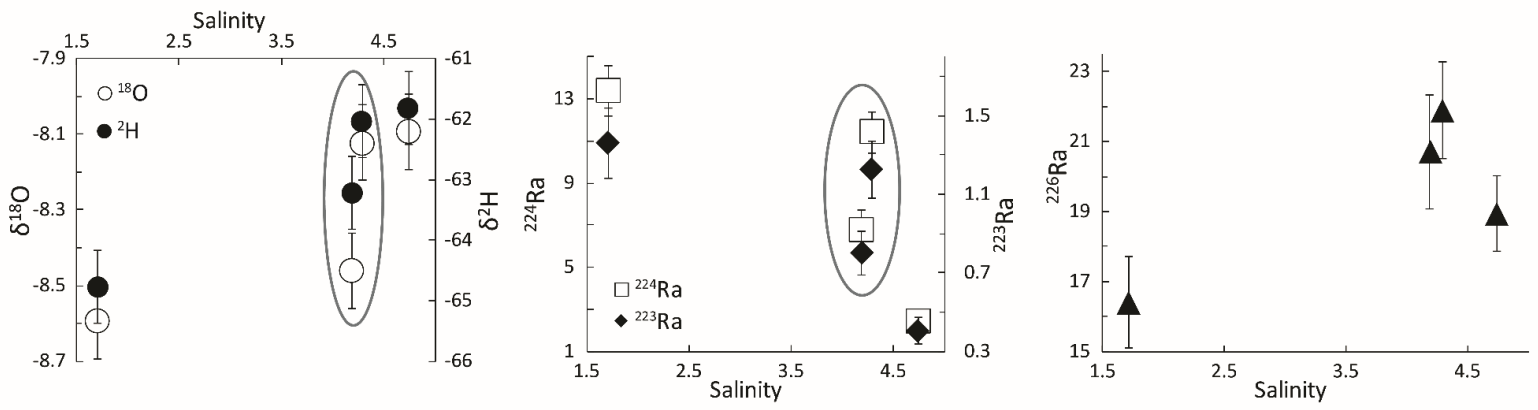

$400 \quad$ Figure 8.a-c: (a) $\delta^{2} \mathrm{H}$ and $\delta^{18} \mathrm{O}$, (b) ${ }^{223} \mathrm{Ra},{ }^{224} \mathrm{R}$, and (c) ${ }^{226} \mathrm{Ra}$ as a function of salinity in

401 Kallrigafjärden bay. Stations KF2 and KF3, which deviate from mixing trend near

402 Börstilåsen, esker circled.

\subsection{Ra mass balance and SGD rate estimation}

406

407 investigated area. $J_{\lambda}$ is simply the mean excess Ra activity observed on the site multiplied by

418 the decay constant. Resulting fluxes are in units of $\mathrm{dpm} \mathrm{d}^{-1}$.

where $J_{\text {sed }}$ and $J_{\text {SGD }}$ denote the input fluxes of a specific Ra isotope through diffusion from seabed sediments and from SGD, respectively while $J_{\text {sea }}$ and $J_{\lambda}$ the output fluxes through export to the open Baltic Sea and radioactive decay. $J_{\text {sed }}$ can be constrained using the results of the sediment diffusion experiment (Section 4.5). To constrain $J_{\text {sea }}$ requires determination of the excess inventory of the $\mathrm{Ra}$ isotope and the residence time of seawater within the 
419 Since a ${ }^{224} \mathrm{Ra}_{\mathrm{xs}}$ gradient was observed and more stations were enriched in ${ }^{224} \mathrm{Ra}_{\mathrm{xs}}$ than in $420{ }^{223}{ }^{2 a},{ }^{224} \mathrm{Ra}_{\mathrm{xs}}$ activities will be used in the mass balance. A mass balance will not be 421 constructed using ${ }^{226} \mathrm{Ra}$ and ${ }^{228} \mathrm{Ra}$ because the average activities found in Öregrundsgrepen 422 (13.7 and $\left.16.0 \mathrm{dpm} 100 \mathrm{~L}^{-1}\right)$ were not statistically higher than the respective activities reported

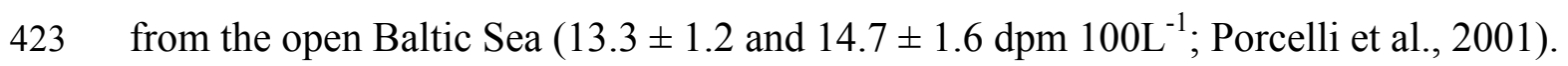

424 Contribution of ${ }^{224} \mathrm{Ra}$ from rivers and precipitation are neglected. ${ }^{228}$ Ra activities of $\sim 4 \mathrm{dpm}$ $425100 \mathrm{~L}^{-1}$ were found at various locations in the Kalix River, which discharges into the northern 426 Gulf of Bothnia (Porcelli et al., 2001). Assuming secular equilibrium between ${ }^{224} \mathrm{Ra}$ and $427{ }^{228} \mathrm{Ra}$, streams would supply only $\sim 10 \%$ of the ${ }^{224} \mathrm{Ra}_{\mathrm{xs}}$ than the average shallow groundwater $428\left(\sim 140 \mathrm{dpm}^{224} \mathrm{Ra}_{\mathrm{xs}} 100 \mathrm{~L}^{-1}\right)$ could supply if shallow SGD comprises $17 \%$ of the total runoff 429 from the Forsmark coast (Section 2).

\subsubsection{Site constraints}

To develop the mass balance, the surface area and volume of seawater affected by SGD must

432 be constrained. A conservative estimate of the ${ }^{224} \mathrm{Ra}_{\mathrm{xs}}$ activity in the open Baltic Sea is found 433 using the lowest ${ }^{224} \mathrm{Ra}_{\mathrm{xs}}$ activity measured in the studied area (station $\mathrm{t} 15,1.0 \pm 0.3 \mathrm{dpm}$ $\left.434{ }^{224} \mathrm{Ra}_{\mathrm{xs}} 100 \mathrm{~L}^{-1}\right)$. The area affected by SGD is then considered to include only those stations 435 with ${ }^{224} \mathrm{Ra}_{\mathrm{xs}}$ activities statistically higher than the open sea ${ }^{224} \mathrm{Ra}_{\mathrm{xs}}$ activity (stations $\mathrm{t} 1-4, \mathrm{t} 6-7$, $436 \mathrm{t} 9, \mathrm{t} 11-12$, and $\mathrm{t} 14$; denoted by $*$ in Table 1$)$. Thus, the area influenced by SGD is $16 \cdot 10^{6} \mathrm{~m}^{2}$. 437 An average depth of $11 \mathrm{~m}$, which represents the depth of the water column averaged over the 438 stations constrained as influenced by SGD, is used to constrain the volume of brackish water 439 influenced by SGD to $180 \cdot 10^{6} \mathrm{~m}^{3}$.

\subsubsection{Residence time}

441 A residence time, which represents the time elapsed since Ra isotopes were transferred from 442 their source to the constrained study site, is required to estimate the flux of Ra exported 
offshore. One such age model, developed by Moore (2006), is expressed through the equation:

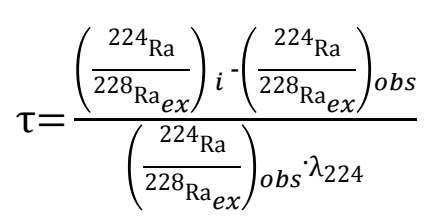

where $i$ denotes the initial end-member Ra activity and $o b s$ the average ${ }^{224} \mathrm{Ra}_{\mathrm{ex}}{ }^{228} \mathrm{Ra}_{\mathrm{ex}}$ activity ratio observed within the constrained site. The subscript "ex" denotes the observed coastal ${ }^{224} \mathrm{Ra}_{\mathrm{xs}}$ or ${ }^{228} \mathrm{Ra}$ activity subtracted by the offshore activity (i.e. the Ra signal corrected for mixing with open seawater). An offshore ${ }^{228} \mathrm{Ra}$ activity of $14.7 \mathrm{dpm} 100 \mathrm{~L}^{-1}$, reported by Porcelli et al. (2001) from the central Gulf of Bothnia, was used to derive ${ }^{228} \mathrm{Ra}_{\mathrm{ex}}$, the mean of which was $1.6 \mathrm{dpm} 100 \mathrm{~L}^{-1}$. ARs involving ${ }^{224} \mathrm{Ra}$ are used because the residence time is likely on the order of days, considering the size of the investigation site. This model relies on the assumption that $\mathrm{Ra}$ is removed from the system only through radioactive decay and exchange with open-sea waters. The initial end-member activity, $i$, will depend on the amount of ${ }^{224} \mathrm{Ra}_{\mathrm{xs}}$ and ${ }^{228} \mathrm{Ra}$ supplied to the seawater by SGD and sediment diffusion. Since this term is unknown, the highest ${ }^{224} \mathrm{Ra}_{\mathrm{ex}} /{ }^{228} \mathrm{Ra}_{\mathrm{ex}} \mathrm{AR}$ of $(5.9, \mathrm{t} 1)$ is here used under the assumption that this ratio is found closest to the Ra source so that minimum decay is expected.

A residence time of $12 \pm 14$ days was obtained using ${ }^{224} \mathrm{Ra}_{\mathrm{ex}}{ }^{228} \mathrm{Ra}_{\mathrm{ex}}$ ARs of the constrained 459 site. The uncertainty is large due to the propagation of analytical uncertainty combined with 460 low Ra activities. However, the Ra-based $T_{R}$ model agrees with previous hydrological 461 models, which determined a residence time of 9-11 days for the spring season (Engqvist, 462 1999). Provided the lower uncertainty of the hydrological model, a residence time of $11 \pm 2$ 463 days is used to reduce the uncertainty propagated to the mass balance calculation. 


\subsubsection{Contribution from sediments}

The experimental ${ }^{224} \mathrm{Ra}_{\mathrm{xs}}$ diffusive flux (32 $\pm 1.8 \mathrm{dpm} \mathrm{m}^{-2} \mathrm{~d}^{-1}$; Section 4.3.3) can be converted to total ${ }^{224} \mathrm{Ra}_{\mathrm{xs}}$ flux from sediments by multiplying them by the surface sediment area of the investigation site $\left(16 \cdot 10^{6} \mathrm{~m}^{2}\right)$, under the assumption that the core sample represents sediments homogeneously distributed across the seabed of the constrained site. The resulting ${ }^{224} \mathrm{Ra}_{\mathrm{xs}}$ flux from sediment diffusion $\left(\mathrm{J}_{\mathrm{sed}}\right)$ is $(520 \pm 31) \cdot 10^{6} \mathrm{dpm} \mathrm{d}^{-1}$.

\subsubsection{Selection of SGD end-member}

At Forsmark, salinity, $\delta^{2} \mathrm{H}, \mathrm{Ca} / \mathrm{Mg}$ ratios, and ${ }^{228} \mathrm{Ra} /{ }^{226} \mathrm{Ra}$ ARs can neither be used to define the groundwater source of SGD nor to determine whether the deep or shallow groundwater is discharging (Section 5.3). However, the groundwater end-member can be selected based on the hydrological understanding of the site. For instance, the SFM0059 is a plausible shallow groundwater end-member because it is sampled from the Börstilåsen esker, a potential SGD channel (Section 2). This shallow groundwater probably mixes with some deep groundwater component sourced by the fracture network. To constrain a minimum rate of SGD, the shallow and deep groundwaters which had the highest ${ }^{224} \mathrm{Ra}_{\mathrm{xs}}$ activities (SFM0059 and KFR01, respectively) are used in the SGD rate calculation.

\subsubsection{SGD rate estimation}

The coastal ${ }^{224} \mathrm{Ra}_{\mathrm{xs}}$ inventory, or the total activity of ${ }^{224} \mathrm{Ra}_{\mathrm{xs}}$ in the volume of brackish water influenced by SGD (Section 4.1.1), must be established for the mass balance (Equation 2). The inventory is determined by 1) multiplying the ${ }^{224} \mathrm{Ra}_{\mathrm{xs}}$ activities of the stations within the constrained site by respective water column depth, 2) averaging the results of (1) (in dpm $\mathrm{m}^{-}$ $\left.{ }^{2}\right)$, and 3) multiplying (2) by surface area of the constrained site $\left(16 \cdot 10^{6} \mathrm{~m}^{2}\right)$. The resulting inventory, $(4800 \pm 1700) \cdot 10^{6} \mathrm{dpm}$, can then be apportioned into $J_{\text {sea }}, J_{\text {sed }}, J_{\lambda}$, and $J_{S G D}$ (in $\left.\mathrm{dpm} \mathrm{d}^{-1}\right)$ 
$J_{\text {sea, }}$ the flux of Ra exported to the open sea, is determined from the excess inventory, i.e. the difference between the total ${ }^{224} \mathrm{Ra}_{\mathrm{x}}$ inventory within the site and that supplied by the open sea (conservatively estimated to $1.3 \mathrm{dpm} 100 \mathrm{~L}^{-1}$, Section 5.4.1), divided by the residence time (11 $\pm 2 \mathrm{~d})$. This results in a $J_{\text {sea }}$ of $(260 \pm 160) \cdot 10^{6} \mathrm{dpm}^{224} \mathrm{Ra}_{\mathrm{xs}} \mathrm{d}^{-1}$.

The flux of ${ }^{224} \mathrm{Ra}_{\mathrm{xs}}$ removal through radioactive decay, $J_{\lambda}$, is obtained by multiplying the total ${ }^{224} \mathrm{Ra}_{\mathrm{xs}}$ inventory $\left.(4800 \pm 1700) \cdot 10^{6} \mathrm{dpm}\right)$ by the decay constant of ${ }^{224} \mathrm{Ra}\left(0.189 \mathrm{~d}^{-1}\right)$. The resulting flux of ${ }^{224} \mathrm{Ra}_{\mathrm{xs}}$ removal by decay is $(900 \pm 310) \cdot 10^{6} \mathrm{dpm} \mathrm{d}^{-1}$.

Table 2: Calculated mass balance inputs* and SGD rate ranges.

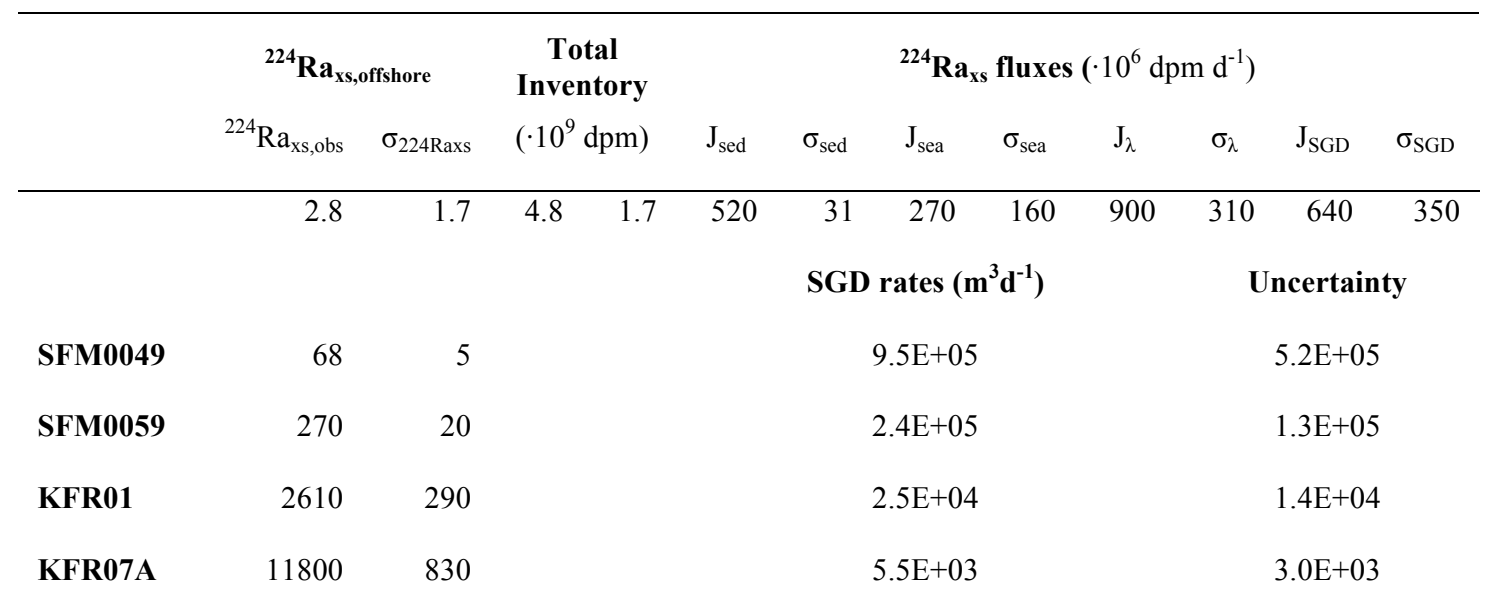

*Surface area of $16 \cdot 10^{6}$, an average depth of $11 \mathrm{~m}$, and a volume of $180 \cdot 10^{6} \mathrm{~m}^{3}$ used to calculate fluxes.

Rearranging Equation 2 to $J_{S G D}=J_{\text {sea }}+J_{\lambda}-J_{\text {sed }}$ yields an SGD-derived ${ }^{224} \operatorname{Ra}_{\mathrm{xs}}$ flux of $(640 \pm$ $350) \cdot 10^{6} \mathrm{dpm} \mathrm{d}^{-1}$. The flow rate is obtained by dividing this flux with the ${ }^{224} \mathrm{Ra}_{\mathrm{xs}}$ activity of the end-member groundwaters (Table 2). The resulting SGD rate ranges from $(5.5 \pm 3.0)$. $10^{3}$ to $(950 \pm 520) \cdot 10^{3} \mathrm{~m}^{3} \mathrm{~d}^{-1}$ (or $3.4 \cdot 10^{-4}$ to $5.8 \cdot 10^{-2} \mathrm{~m}^{3} \mathrm{~m}^{-2} \mathrm{~d}^{-1}$ ) depending on whether the end-member is comprised of entirely deep or shallow groundwater, respectively. In reality, SGD is probably comprised of a mixture between shallow and deep groundwater, thus an SGD flow between the two estimates is expected. Proportions deep and shallow groundwater contribution the coastal has not been determined. 


\subsubsection{Recirculated component of SGD}

509 Previous hydrological models of the Forsmark area determined a shallow fresh groundwater 510 discharge rate of $\sim 2.4 \cdot 10^{3} \mathrm{~m}^{3} \mathrm{~d}^{-1}$ or $1.5 \cdot 10^{-4} \mathrm{~m}^{3} \mathrm{~m}^{-2} \mathrm{~d}^{-1}$ (Jarsjö et al. 2008), which is two

511 orders of magnitude lower than the ${ }^{224} \mathrm{Ra}_{\mathrm{xs}}$-derived discharge rate of shallow groundwater.

512 Therefore, the SGD rate derived from ${ }^{224} \mathrm{Ra}$ indicates that a component of recirculated

513 seawater, independent of inland hydraulic head, is important in Öregrundsgrepen. When

514 seawater is driven into the coastal aquifer and discharged back into the sea, the generally short

515 residence time in the coastal aquifer allows the water to become enriched in ${ }^{223} \mathrm{Ra}$ and ${ }^{224} \mathrm{Ra}$,

516 which are rapidly regenerated by aquifer solids, over ${ }^{226} \mathrm{Ra}$ and ${ }^{228} \mathrm{Ra}$ (Leuk \& Beck, 2014).

517 Therefore, ${ }^{223} \mathrm{Ra}$ and ${ }^{224} \mathrm{Ra}$ enrichment has been observed in the absence of ${ }^{226} \mathrm{Ra}$ and ${ }^{228} \mathrm{Ra}$

518 gradients due to the dominance of a short-scale, recirculated seawater component of SGD in

519 Öregrundsgrepen.

Tidal cycles (Robinson et al., 2007), geothermal convection (Wilson, 2005), waves (Li,

521 2007), currents and irregular bathymetry (Thibodeaux \& Boyle, 1987) have been shown to

522 support seawater recirculation. Although tidal cycles are insignificant in the Baltic Sea, the

523 mean sea level change in Öregrundsgrepen is $0.02 \pm 0.2 \mathrm{~m} \mathrm{~d}^{-1}$ but can change by up to $1.3 \mathrm{~m}$

$524 \mathrm{~d}^{-1}$ as a result of changes in atmospheric pressure and wind (Aquilonius 2010). The wind 525 speed in the strait is typically higher than $6.5 \mathrm{~m} \mathrm{~s}^{-1}$ and is frequently higher than $10.5 \mathrm{~m} \mathrm{~s}^{-1}$

526 (Larsson-McCann et al., 2002). Geothermal convection may also drive seawater recirculation

527 in this region, as Söderberg \& Flodén (1997) observed contrasting temperatures between

528 warm water seeping from seafloor eskers and cold seawater during early spring in the

529 Stockholm archipelago, $200 \mathrm{~km}$ south of Öregrundsgrepen. Finally, the entire Baltic Sea basin

530 has developed irregular bathymetry through glacial erosion and sediment deposition (Voipio, 531 1981). 
532 The rate of fresh SGD to Öregrundsgrepen $\left(1.5 \cdot 10^{-4} \mathrm{~m}^{3} \mathrm{~m}^{-2} \mathrm{~d}^{-1}\right.$; Jarsjö et al., 2008) is lower

533 than the SGD rates found in the Bay of Puck, Poland (up to $2.8 \cdot 10^{-2} \mathrm{~m}^{3} \mathrm{~m}^{-2} \mathrm{~d}^{-1}$ ) and

534 Eckernförde Bay, Germany $\left(9 \cdot 10^{-3} \mathrm{~m}^{3} \mathrm{~m}^{-2} \mathrm{~d}^{-1}\right)($ Symczycha and Pempkowiak, 2016; Schlüter 535 et al., 2004, respectively), which are the only two locations in the Baltic Sea where 536 geochemical studies of SGD have been conducted. Consideration of a recirculated component 537 in Öregrundsgrepen increases the SGD rate to $5.8 \cdot 10^{-2} \mathrm{~m}^{3} \mathrm{~m}^{-2} \mathrm{~d}^{-1}$, which is higher than that 538 reported from the southern Baltic. While the importance of a recirculated component in 539 delivering nutrients and metals to the Baltic Sea is yet unknown, recirculated seawater is an 540 important source of nutrients to the coastal ocean (Weinstein et al., 2011). Accurate 541 determination of SGD-driven nutrient fluxes to the Baltic Sea represents an important area of 542 future research. Finally, it will be valuable to further understand the impact of geothermal 543 convection, irregular bathymetry, and fluctuations in atmospheric pressure on seawater recirculation, an important route of nutrient transport even in the absence of inland hydraulic 545 head.

\section{Conclusions}

This study has shown that Ra isotopes can provide estimates of residence time and SGD flow rate at salinities less than five. Ra and stable isotopes have also been used to identify zones of

549 groundwater discharge related to geologic features. Diffusion from seabed sediment is a 550 source of ${ }^{223} \mathrm{Ra}$ and ${ }^{224} \mathrm{Ra}_{\mathrm{xs}}$ to the Gulf of Bothnia, amounting to $\sim 10 \%$ of the total ${ }^{224} \mathrm{Ra}_{\mathrm{xs}}$ 551 inventory in Öregrundsgrepen.

552 The ${ }^{224} \mathrm{Ra}_{\mathrm{xs}}$-derived SGD flow rate ranged between $(5.5 \pm 3.0) \cdot 10^{3}$ and $(950 \pm 520) \cdot 10^{3} \mathrm{~m}^{3}$

$553 \mathrm{~d}^{-1}$. The precise rate depends on the relative contributions of deep and shallow groundwater,

554 which are unknown. Nevertheless, these rates are higher than would be expected from $\delta^{2} \mathrm{H}$, $555 \delta^{18} \mathrm{O}$, and $\mathrm{Ca} / \mathrm{Mg}$ ratio mixing calculations. Therefore, a component of recirculated brackish 
water is significant in Öregrundsgrepen despite a modest, inland hydraulic head. Since this is a potential source of metals and nutrients to the coast, these findings have important implications on mass transport to the Baltic Sea and other low-relief coastal terrains.

Furthermore, hydrological models of the Forsmark site, constructed to understand radionuclide transport from the existing and planned radioactive waste repositories, have not considered a recirculated brackish water component in Öregrundsgrepen. If this can be considered a near-surface process, the effects on radionuclide transport at Forsmark is probably small. Nevertheless, the impact of recirculated seawater should not be overlooked, because coastal regions as prominent locations for nuclear power plants (World Nuclear Association, 2015), are becoming attractive hosts for radioactive waste repositories. Clearly, Ra isotope analysis is a viable and important complement to the models of sites proposed to host repositories.

\section{Acknowledgements}

The authors are grateful to Cecilia Berg, Micke Borgiel, Ignasi Puigdomenech, and Karin Wallner for their assistance in field and laboratory work. This article benefitted from critical reviews by Patrik Vidstrand, Emma Johansson, and Lena Evins. This study was supported by the Swedish Nuclear Fuel and Waste Management Company and the European Union's Seventh Framework Programme for research, technological development, and demonstration under Grant Angreement No. 290336. V.R. has received funding from the European Union's

576 Horizon 2020 research and innovation programme under the Marie Skłodowska-Curie grant agreement No 748896. Support provided by the Generalitat de Catalunya to MERS (2014 SGD - 1356) is also acknowledged. 


\section{References}

Aquilonius, K. (Ed.), 2010. The marine ecosystems at Forsmark and Laxemar-Simpevarp. SR-Site Biosphere. SKB TR-10-03. SKB, Stockholm, Sweden.

Beck, A.J., Rapaglia, J.P., Cochran, J.K., Bokuniewicz, H.J., 2007. Radium mass-balance in Jamaica Bay, NY: Evidence for a substantial flux of submarine groundwater. Mar. Chem. 106, 419-441.

Boehm, A.B., Shellenbarger, G.G., Paytan, A., 2004. Groundwater discharge: Potential association with fecal indicator bacteria in the surf zone. Environ. Sci. Technol. 38, 3558-3566.

Borgiel, M., 2003. Forsmark site investigation: Sampling and analyses of surface sediment in lakes and shallow bays. SKB P-04-05, SKB, Stockholm, Sweden.

Burnett, W.C., Bokuniewics, H., Huettel, M., Moore, W.S., Taniguchi, M., 2003. Groundwater and pore water inputs to the coastal zone. Biogeochemistry 66, 3-33.

Charette, M.A., Buesseler, K.O., Andrews, J.E., 2001. Utility of radium isotopes for evaluating the input and transport of groundwater-derived nitrogen to a Cape Cod estuary. Limnol. Oceanogr. 46, 465-470.

Charette, M.A., Moore, W.S., \& Burnett, W.C., 2008. Uranium-and thorium-series nuclides as tracers of submarine groundwater discharge, in: Krishnaswami, S., Cochran J.K. (Eds.), Radioactivity in the Environment, Vol 13. Elsevier, Oxford, pp. 155-191.

Elsinger, R.J., Moore,W.S., 1980. ${ }^{226}$ Ra behavior in the Pee Dee River-Winyah Bay estuary. Earth Planet. Sci. Lett. 48, 239-249.

Engvist, A., Andrejev, O., 1999. Water exchange of Öregrundsgrepen: A baroclinic 3-D model study. SKB TR-99-11. SKB, Stockholm, Sweden.

Engqvist, A., Döös, K., Andrejev, O., 2006. AMBIO 35, 435-447.

Follin, S., Johansson, P.-O., Levén, J., Hartley, L., Holton, D., McCarthy, R., Roberts, D., 2007. Updated strategy and test of new concepts for groundwater flow modelling in Forsmark in preparation of site descriptive modelling stage 2.2. SKB R-07-20. SKB, Stockholm, Sweden.

Fröhlich, K., Grabczak, J., Rozanski, K., 1988. Deuterium and oxygen-18 in the Baltic Sea. Chem. Geol. 72, 77-83.

Garcia-Orellana, J., Cochran, J.K., Bokuniewicz, H., Daniel, J.W.R., Rodellas, V., Heilbrun, C., 2014. Evaluation of ${ }^{224} \mathrm{Ra}$ as a tracer for submarine groundwater discharge in Long Island Sound (NY). Geochim. Cosmochim. Acta 141, 314-330. 
Garcia-Solsona, E., Garcia-Orellana, J., Masque, P., Rodellas, V., Mejias, M., Ballesteros, B., Dominquez, J.A., 2010. Groundwater and nutrient discharge through karstic coastal springs (Castello, Spain). Biogeosciences 7, 2625-2638.

Garcia-Solsona, E., Masqué, P., Garcia-Orellana, J., Rapaglia, J., Beck, A.J., Cochran, J.K., Bokuniewicz, H.J., Zaggia, L., Collavini, F., 2008. Estimating submarine groundwater discharge around Isola La Cura, northern Venice Lagoon (Italy), by using the radium quartet. Mar. Chem. 109, 292-306.

Gu, H., Moore, W.S., Zhang, L., Du, J., Zhang, J., 2012. Using radium isotopes to estimate the residence time and the contribution of submarine groundwater discharge (SGD) in the Changjiang effluent plume, East China Sea. Cont. Shelf Res. 35, 95-107.

Hedenström, A., Sohlenius, G., Strömgren, M., Brydsten, L., Nyman, H., 2008. Depth and stratigraphy of regolith at Forsmark, site descriptive modelling Forsmark. SKB R-0807. SKB, Stockholm, Sweden.

Jakobsson, M., O’Regan, M., Gyllencreutz, R., Flodén, T., 2016. Seafloor terraces and semicircular depressions related to fluid discharge in Stockholm Archipelago, Baltic Sea, in: Dowdeswell, J. A., Canals, M., Jakobsson, M., Todd, B. J., Dowdeswell, E. K., Hogan, K. A. (Eds.), Atlas of Submarine Glacial Landforms: Modern, Quaternary and Ancient. Geological Society, London, Memoirs 46, pp. 305-306.

Jarsjö, J., Shibuo, Y., Destouni, G., 2008. Spatial distribution of unmonitored inland water flows to the sea. J. Hydrol. 348, 59-72.

Krest, J.M., Moore, W.S., Rama, 1999. ${ }^{226} \mathrm{Ra}$ and ${ }^{228} \mathrm{Ra}$ in the mixing zones of the Mississippi and Atchafalaya Rivers: indicators of groundwater input. Mar. Chem. 64, 129-152.

Kwon, E. Y., Kim, G., Primeau, F., Moore, W.S., Cho, H.-M., DeVries, T., Sarmiento, T.L., Charette, M.A., Cho, Y.-K., 2014. Global estimate of submarine groundwater discharge based on an observationally constrained radium isotope model. Geophys. Res. Lett. 41, 8438-8444.

Laaksoharju, M., Smellie, J., Tullborg, E.-L., 2008. Bedrock hydrogeochemistry Forsmark, site descriptive modelling Forsmark. SKB R-08-47. SKB, Stockholm, Sweden.

Larsson-McCann, S., Karlsson, A., Nord, M., Sjögren, J., Johansson, L., Ivarsson, M., Kindell, S., 2002. Meteorological, hydrological and oceanographical information and data for site investigation program in the communities of Östhammar and Tierp in the northern part of Uppland. SKB TR-02-02. SKB, Stockholm, Sweden.

Leuk, J.L., Beck, A.J., 2014. Radium budget of the York River estuary (VA, USA) dominated by submarine groundwater discharge with a seasonally variable groundwater endmember. Mar. Chem. 165, 55-65.

Li, L., Barry, D.A., 2000. Wave-induced beach groundwater flow. Adv. Water Resour. 23, 325-337. 
Li, Y., Chan, L., 1979. Desorption of Ba and ${ }^{226} \mathrm{Ra}$ from river-borne sediments in the Hudson estuary. Earth Planet. Sci. Lett. 43, 343-350.

Gonneea, M.E., Morris, P.J., Dulaiova, H., Charette, M.A., 2008. New perspectives on radium behavior within a subterranean estuary. Mar. Chem. 109, 250-267.

Moore, W.S., Arnold, R., 1996. Measurement of ${ }^{223} \mathrm{Ra}$ and ${ }^{224} \mathrm{Ra}$ in coastal waters using a delayed coincidence counter. J. Geophys. Res. 101, 1321-1329.

Moore, W. S., Astwood, H., Lindstrom, C., 1995. Radium isotopes in coastal waters on the Amazon shelf. Geochim. Cosmochim. Acta 59, 4285-4298.

Moore, W., Blanton, J., Joye, S., 2006. Estimates of flushing times, submarine groundwater discharge, and nutrient fluxes to Okatee River, South Carolina. J. Geophys. Res. Oceans 111, C09006, doi: 10.1029/2005JC003041.

Moore, W.S., 2010. The effect of submarine groundwater discharge on the ocean. Annu. Rev. Mar. Sci. 2, 59-88.

Moore, W.S., Reid, D.F., 1973. Extraction of radium from natural waters using manganese impregnated acrylic fibers. J. Geophys. Res. 78, 8880-8886.

Moore, W.S., Sarmiento, J.L., Key, R.M., 2008. Submarine groundwater discharge revealed by ${ }^{228} \mathrm{Ra}$ distribution in the upper Atlantic Ocean. Nat. Geosci. 1, 309-311.

Porcelli, D., Andersson, P.S., Baskaran, M., Wasserburg, G.J., 2001. Transport of U- and Thseries nuclides in a Baltic Shield watershed and the Baltic Sea. Geochim. Cosmochim. Acta 65, 2439-2459.

Povinec, P.P., Aggarwal, P.K., Aureli, A., Burnett, W.C., Kontar, E.A., Kulkarni, K.M., Moore, W.S., Rajar, R., Taniguchi, M., Comanducci, J.F., Cusimano, G., Dulaiova, H., Gatto, L., Groening, M., Hauser, S., Levy-Palomo, I., Oregioni, B., Ozorovich, Y.R., Privitera, A.M., Schiavo, M.A., 2006. Characterisation of submarine groundwater discharge offshore south-eastern Sicily. J. Environ. Radioact. 89, 51101.

Raanan Kiperwas, H., 2011. Radium Isotopes as Tracers of Groundwater-Surface Water Interactions in Inland Environments. $\mathrm{PhD}$ dissertation, Duke University.

Robinson, C., Li, L., Barry, D.A., 2007. Effect of tidal forcing on a subterranean estuary. Adv. Water Resour. 30, 851-865.

Rodellas, V., Garcia-Orellana, J., Garcia-Solsona, E., Masque, P., Dominguez, J., Ballesteros, B.J., Mejias, M., Zarroca, M., 2012. Quantifying groundwater discharge from different sources into a Mediterranean wetland by using ${ }^{222} \mathrm{Rn}$ and Ra isotopes. J. Hydrol. 466, $11-22$. 
Rodellas, V., Garcia-Orellana, J., Masqué, P., Font-Muñoz, J.S., 2015. The influence of sediment sources on radium-derived estimates of submarine groundwater discharge. Mar. Chem. 171, 107-117

Rodellas, V., Garcia-Orellana, J., Tovar-Sánchez, A., Basterretxea, G., López-Garcia, J. M., Sánchez-Quiles, D., Garcia-Solsona, E., Masqué, P., 2014. Submarine groundwater discharge as a source of nutrients and trace metals in a Mediterranean bay (Palma Beach, Balearic Islands). Mar. Chem. 160, 56-66.

Rodellas, V., Garcia-Orellana, J., Trezzi, G., Masqué, P., Stieglitz, T.C., Bokuniewicz, H., Kirk Cochran, J., Berdalet, E., 2017. Using the radium quartet to quantify submarine groundwater discharge and porewater exchange. Geochim. Cosmochim. Acta 196, 5873.

Schlüter, M., Sauter, E.J., Andersen, C.A., Dahlgaard, H., Dando, P.R., 2004. Spatial distribution and budget for submarine groundwater discharge in Eckernförde Bay (Western Baltic Sea). Limnol. Oceanogr. 49, 157-167

SKB, 2008. Site description of Forsmark at completion of the site investigation phase-SDMSite Forsmark. SKB TR-08-05. SKB, Stockholm, Sweden.

Smellie, J., Tullborg, E.-L., Nilsson, A.C., Sandström, B., Waber, N., Gimeno, M., Gascoyne, M. Explorative analysis of major components and isotopes-SDM-Site Forsmark, 2008. SKB R-08-84. SKB, Stockholm, Sweden.

Söderberg, P., Flodén, T., 1997. Stratabound submarine terraces and pockmarks - indicators of spring sapping in glacial clay, Stockholm Archipelago, Sweden, in: Cato, I., Klingberg, F. (Eds.), Porceedings of the Fourth Marine Geological Conference- the Baltic, Uppsala 1995.

Su, N., Jinzhou, D., Zonglian, D., Bing, D., Jing, Z., 2015. Radium isotopes and their environmental implications in the Changjiang River System. Estuar. Coast. Shelf Sci. $156,155-164$.

Sun, Y., Torgersen, T., 1998. The effects of water content and Mn-fiber surface conditions on measurement by emanation. Mar. Chem. 62, 299-306.

Swarzenski, P.W., Simonds, F.W., Paulson, T., Kruse, S., Reich, C.D., 2007. A Geochemical and Geophysical Examination of Submarine Groundwater Discharge and Associated Nutrient Loading Estimates into Lynch Cove, Hood Canal, WA. Environ. Sci. Technol. 41, 7022-7029.

Swarzenski, P.W., Izbicki, JA., 2009. Examining coastal exchange processes within a sandy beach using geochemical tracers, seepage meters and electrical resistivity. Estuar. Coast. Shelf Sci. 83, 77-89.

Symczycha, B., Pempkowiak, J., 2016. The Role of Submarine Groundwater Discharge as Material Source to the Baltic Sea. Springer. 